\title{
Surveys in Ardahan on the Turkish-Georgian Borderline in 2013 and 2014
}

\section{Sami Patacı and Ergün Laflı}

\section{(2) OpenEdition \\ 1 Journals}

\section{Electronic version}

URL: http://journals.openedition.org/anatoliaantiqua/359

DOI: 10.4000/anatoliaantiqua.359

\section{Publisher}

IFEA

\section{Printed version}

Date of publication: 1 June 2015

Number of pages: 229-248

ISBN: 9782362450600

ISSN: 1018-1946

\section{Electronic reference}

Sami Patacı and Ergün Laflı, « Surveys in Ardahan on the Turkish-Georgian Borderline in 2013 and 2014 », Anatolia Antiqua [Online], XXIII | 2015, Online since 30 June 2018, connection on 18 December 2020. URL : http://journals.openedition.org/anatoliaantiqua/359; DOI : https://doi.org/10.4000/ anatoliaantiqua.359 


\title{
ANATOLIA ANTIQUA ESKI ANADOLU
}

\author{
XXIII
}

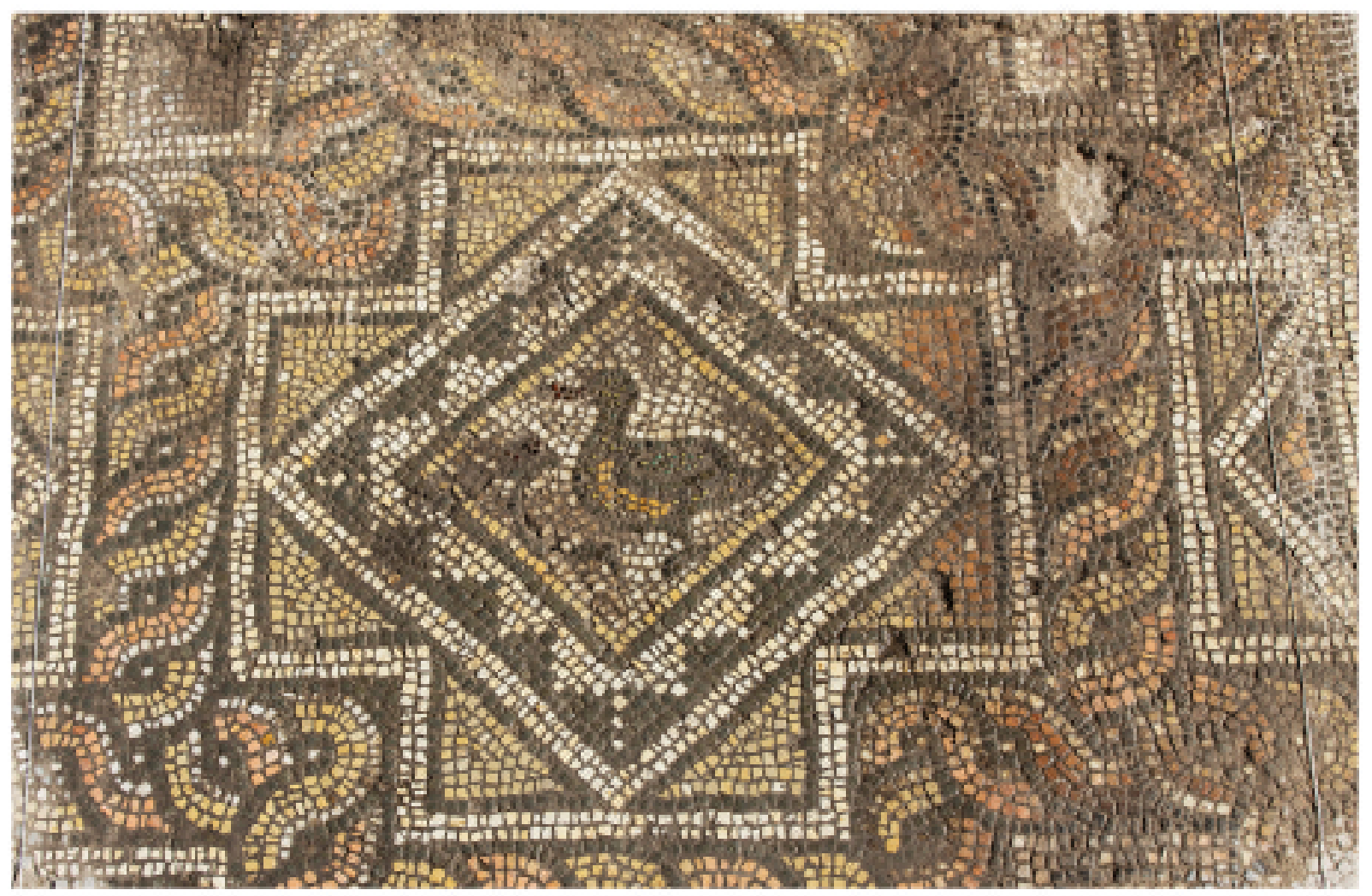

INSTITUT FRANC̣AIS D'ETUDES ANATOLIENNES GEORGES-DUMEZIL CNRS USR 3131 


\section{TABLE DES MATIERES}

Hélène BOUILLON,

On the anatolian origins of some Late Bronze egyptian vessel forms

Agneta FRECCERO,

Marble trade in Antiquity. Looking at Labraunda

Şehnaz ERASLAN,

Dionysus and Ariadne in the light of Antiocheia and Zeugma Mosaics

Ergün LAFLI et Gülseren KAN ŞAHIN,

Middle Byzantine ceramics from Southwestern Paphlagonia

Mustafa AKASLAN, Doğan DEMIRCİ et Özgür PERÇİN en collaboration avec Guy LABARRE, L'église paléochrétienne de Bindeos (Pisidie)

Anaïs LAMESA,

La chapelle des Donateurs à Soğanlı, nouvelle fondation de la famille des Sképidès

Martine ASSENAT et Antoine PEREZ,

Localisation et chronologie des moulins hydrauliques d'Amida. A propos d'Ammien Marcellin,

XVIII, 8,11

Helke KAMMERER-GROTHAUS,

$»$ Ubi Troia fuit«

Atzik-Köy - Eine Theorie von Heinrich Nikolaus Ulrichs (1843)

CHRONIQUES DES TRAVAUX ARCHEOLOGIQUES EN TURQUIE, 2015

Sami PATACI et Ergün LAFLI,

Surveys in Ardahan on the turkish-georgian borderline in 2013 and 2014

Çĭ̆dem MANER,

Preliminary report on the second season of the Konya-Ereğli survey (KEYAR) 2014

Dominique BEYER, Can KARAVUL, Françoise LAROCHE-TRAUNECKER et Aksel TiBBET,

Rapport préliminaire sur les travaux de la mission archéologique de Zeyve Höyük-Porsuk 2014

Jean-Charles MORETTI avec la collaboration de Nicolas BRESCH, Isabel BONORA,

Jean-Jacques MALMARY et Olivier RISS,

Claros, le temple d'Apollon : travaux réalisés en 2014

Olivier HENRY et Erika ANDERSSON, Christophe BOST, Ömür Dünya ÇAKMAKLI, Angela COMMITO, Mélissa CORMIER-HUGUET, Peter DE STAEBLER, Pierre DUPONT, Duygu ERGENÇ, Axel FREJMAN, Banu KEPENEK, Pascal LEBOUTEILLER, Haral NILSSON, Felipe ROJAS, Baptiste VERGNAUD, 


\section{Sami PATACI* and Ergün LAFLI**}

\section{SURVEYS IN ARDAHAN ON THE TURKISH-GEORGIAN BORDERLINE IN 2013 AND 2014}

The Transcaucasus is bordered on the west by the Black Sea and Turkey and it includes the Caucasus Mountains and surrounding lowlands. This region is one of the native areas of the wine-producing vitis vinifera and perhaps the birthplace of wine production. Archaeological excavation and carbon dating of grape pips from the area have dated back to 7000-5000 B.C. ${ }^{1}$ The Province of Ardahan lies on the northeastern border of Turkey to Georgia and has an important geographical position that conjoins Eastern Anatolia with Transaucasia. The city is neighboured with Artvin, the hindermost city of Turkish Eastern Black Sea area in the west, with the cities of Erzurum and Kars in the south and with Georgia and Armenia in the east.

The first surviving record about Ardahan is attributed to Strabo, who calls it as 'Gōgarēnế' and mentions that it was a part of Caucasian Iberia ${ }^{2}$. In the Armenian geography (Asxarhac'oyc'), the city was a district of the province of Gugark (qniqunp) $)^{3}$. The oldest archaeological sites in Ardahan are dated to the Late Chalcolithic and Early Bronze Age. According to the results of some recent studies Ardahan plain was an important landscape for the Transcaucasian cultures of the Bronze Age. Traces of a nomadic culture in Transcaucasia and especially in Georgia have been identified by some archaeological researches and as a result of these today we know that the nomads of this area had existed before the Iron Age.

In some publications Urartians, Cimmerians and Scythians are mentioned in the relationship of the
Iron Age of Ardahan. However, most of the archaeological sites which were attributed to the Kingdom of Urartu have not been studied well in detail and so far there is no archaeological evidence of Cimmerians or Scythians in this region. Apart from a few exceptions, Iron Age seems to be almost entirely a blackout for the plain of Ardahan, especially for the central district of the province. Likewise, there is almost nothing left on surface from the Roman period. On the other hand, Medieval archaeology of Ardahan is quite rich. Medieval Ardahan (১लூ8 ss5o / Artaani in Georgian) is located within the boundaries of the historical region, called 'Tao-Klarjeti' ("

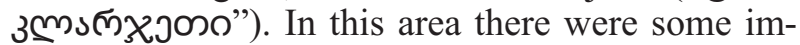
portant geographical districts, such as Samtskhe, Javakheti, Artaani, Erusheti, and Kola. Georgian culture played a significant role in the region since the $4^{\text {th }}$ century B.C. The region was under control of Roman Empire until the $4^{\text {th }}$ century A.D. and Persians ruled over Tao-Klarjeti between the $4^{\text {th }}$ and $6^{\text {th }}$ centuries A.D. Georgian King Vakhtang Gorgasali founded an episcopate during the $5^{\text {th }}$ century in Erusheti which is located in the north of modern Ardahan ${ }^{4}$. Tao-Klarjeti was under the domination of an Arab emirate between the second half of the $7^{\text {th }}$ century and the $9^{\text {th }}$ century. By the end of the $8^{\text {th }}$ century A.D. Georgians take the control around the region and they were most powerful during the $11^{\text {th }}$ $12^{\text {th }}$ centuries A.D. According to the Arab historian Yahya of Antioch, the Byzantines razed Ardahan and slaughtered its population in A.D. $1021^{5}$. The Mongols took hold of the city in A.D. 1230s, but the

*) Ardahan Üniversitesi, İnsani Bilimler ve Edebiyat Fakültesi, Sanat Tarihi Bölüm Başkanlığı, Yenisey Kampüsü, Merkez, TR-75000 Ardahan, Turkey; <samipataci@hotmail.com>.

**) Dokuz Eylül Üniversitesi, Edebiyat Fakültesi, Arkeoloji Bölümü, Tınaztepe/Kaynaklar Yerleşkesi, Buca, TR-35160 Izmir, Turkey; <elafli@yahoo.ca>.

1) Johnson 1989: 17.

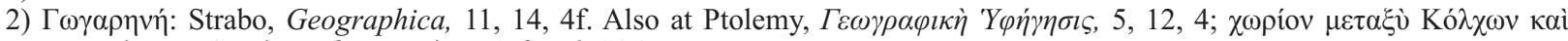

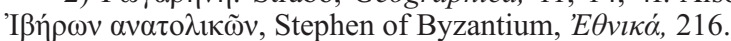

3) Baumgartner 2009: 185.

4) Chant'uria 2014: 165.

5) SAE 1976: 7. 


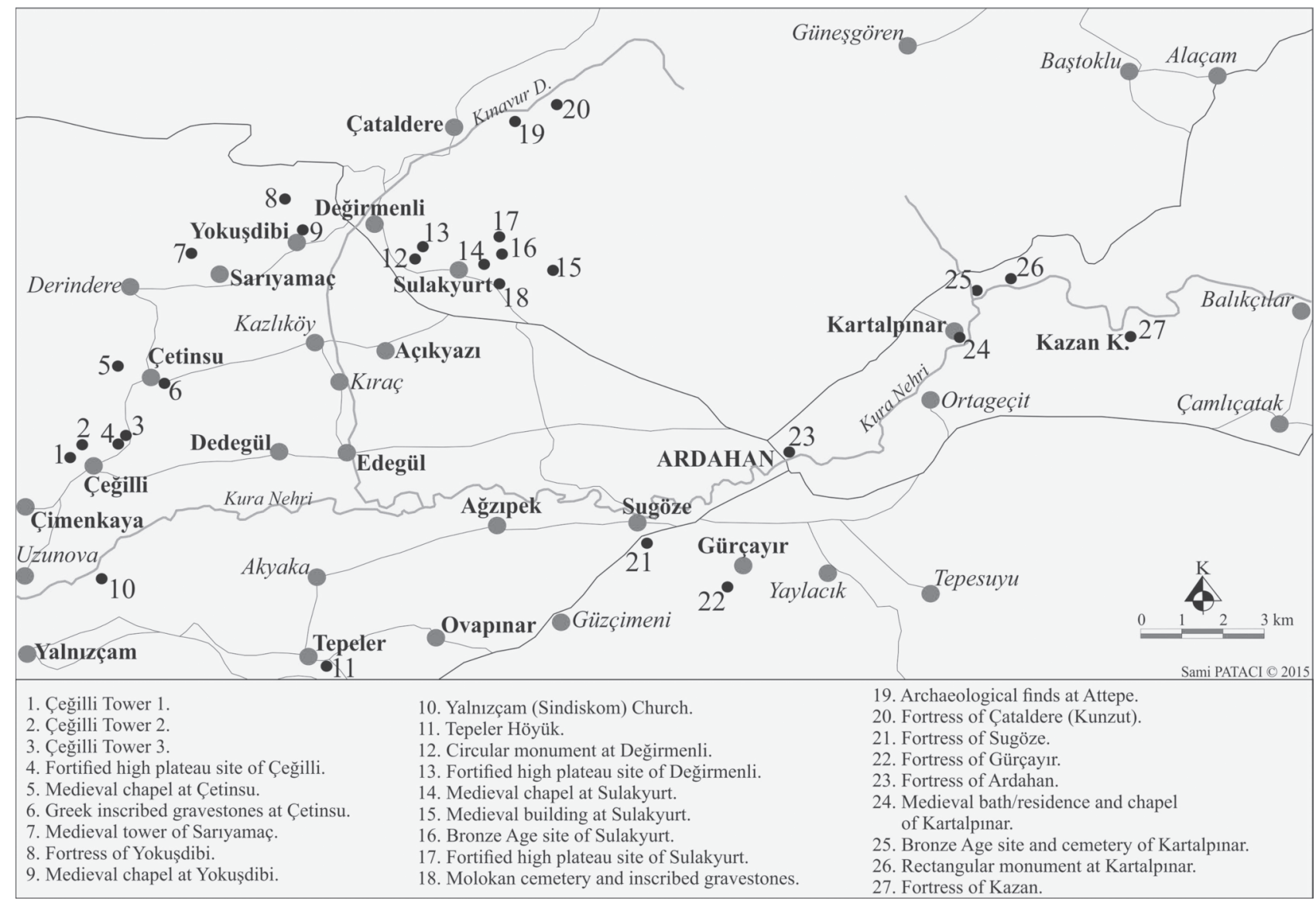

Map 1 : Map of surveyed sites in 2013 and 2014 and archaeological surface find spots in Ardahan (S. Patac1, 2015).

Georgian princes of Samtskhe-Saatabago were able to recapture it in 1266 . The principality of Samtskhe-Saatabago was annexed by the Ottoman Empire in 1555 and Ardahan was included as a sanjak to the Ottoman vilayet (province) of Akhaltsikhe.

An archaeological field survey has begun in this landscape in 2013 by a team mainly consisted of academics from the University of Ardahan ${ }^{6}$. So far the city borders of Ardahan represent a zone that has been studied scholarly at the very least. The landscapes of Ardahan are important especially for the Bronze and Iron Ages and archaeological surveys in 2013 and 2014 have revealed that there are still undiscovered archaeological finds belonging to these periods in central district of Ardahan. At the same time the region seems to be quite rich of Medieval archaeology. Long term scientific excavations are crucially needed in order to specify the exact construction and occupation dates of several sites and monuments and to reveal how the ancient settlement patterns were in this region. In the first place, within the bounds of possibility, a map of the archaeological surface properties of Ardahan has been prepared (Map 1). Since our archaeological knowledge of the provincial centre of Ardahan is very limited, the major aim of our surveys in 2013 and 2014 campaigns was to ascertain the undiscovered archaeological properties in the city centre. Therefore, in the first two seasons concentration is given to the western part of Ardahan and 22 sites were visited (Map 2). These are Tepeler, Yalnızçam, Çeğilli, Yokuşdibi, Ovapınar, Edegül, Dedegül, Ardıçdere, Dağevi, Çatalköprü, Çimenkaya, Akyaka, Ağzıpek, Sugöze, Gürçayır, Sulakyurt, Açıkyazı, Çetinsu, Sarıyamaç, Çataldere, Değirmenli and Kartalpınar. Our archaeological discoveries are as follows: three towers near Çeğilli; three fortified high plateau sites in Çeğilli, Değirmenli and Sulakyurt; remains of a fortress at Yokuşdibi; a Bronze Age site in Sulakyurt; a fortified Bronze Age site and a cemetery in Kartalpınar; a circular monument in Değirmenli; a nearly rectangular monument in Kartalpınar and an unidentified archaeological site in Çataldere. 


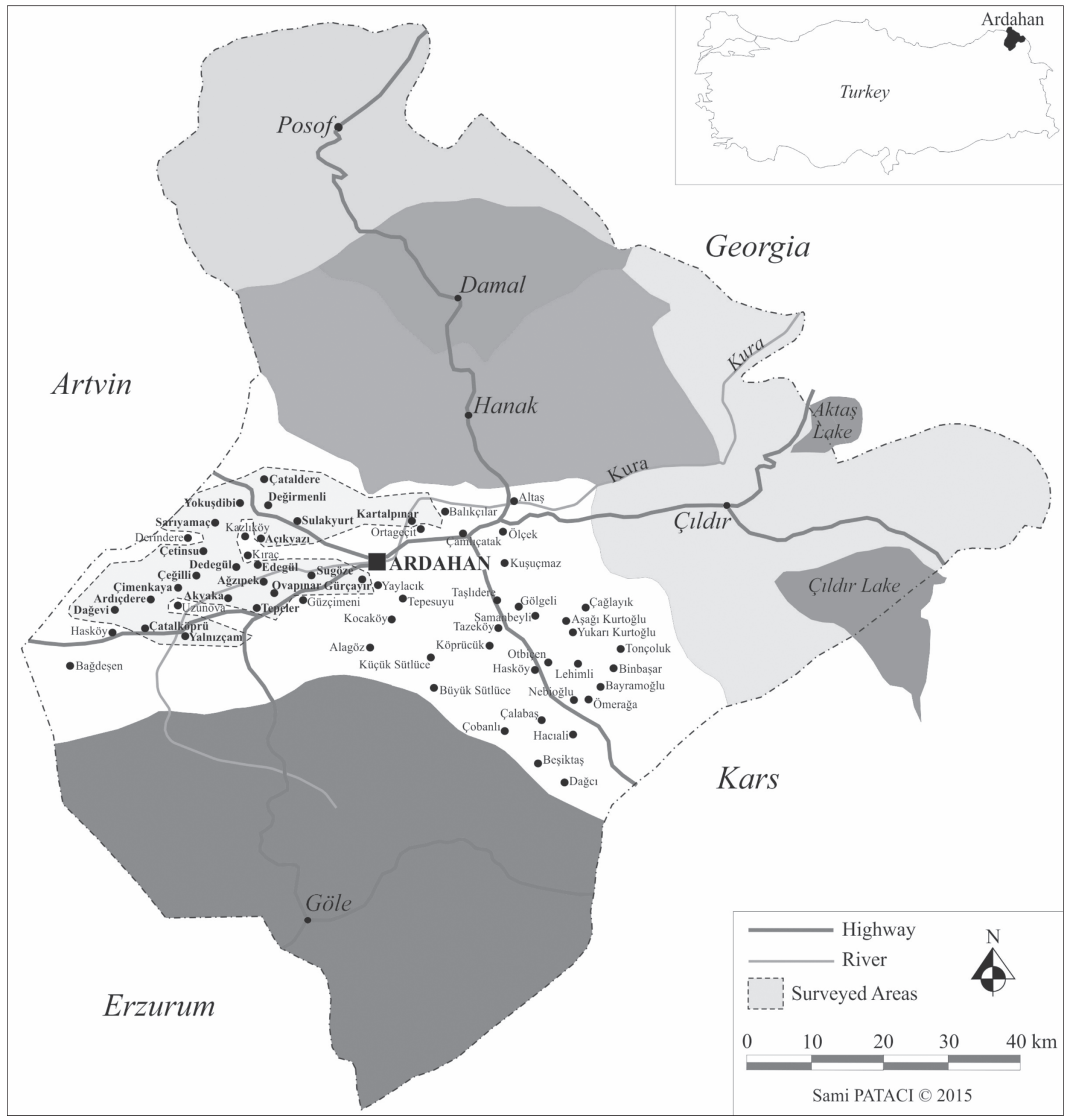

Map 2 : Location of Ardahan with surveyed areas in 2013 and 2014 (S. Patac1, 2015). 


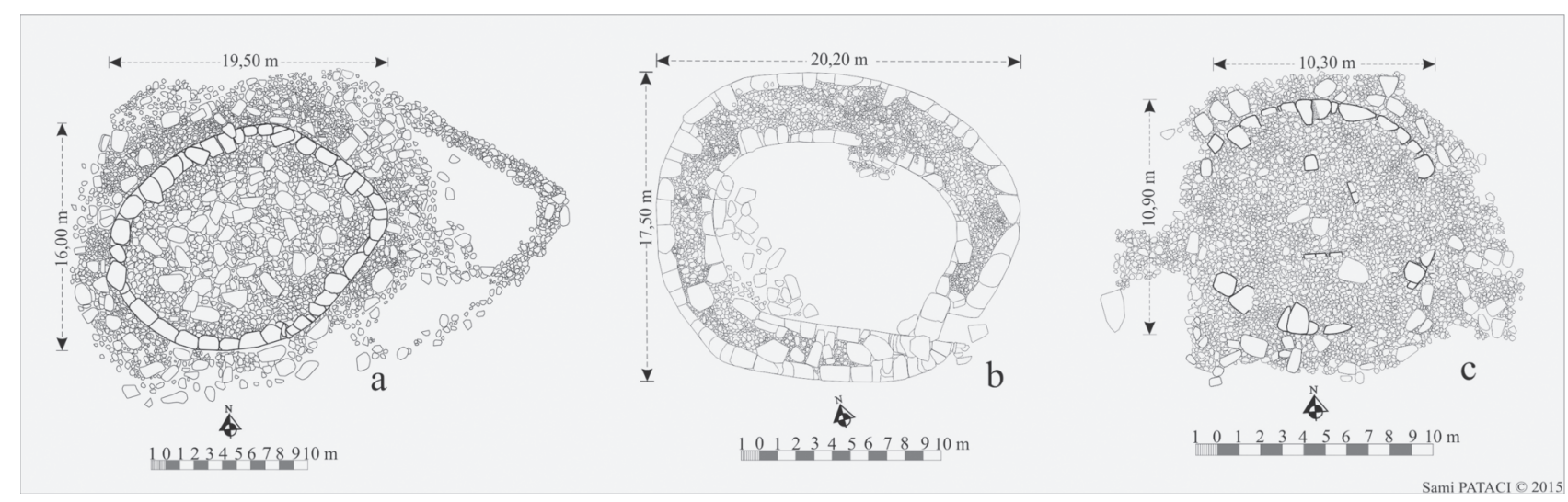

Fig. 1a-c : Plans of the Çeğilli Towers (S. Patacı, 2013).

Ardahan is very rich in term of religious and secular architecture of Medieval and Post-Medieval periods. Several Medieval and Post-Medieval sites were visited during 2013 and 2014 seasons. Two inscribed gravestones in Greek from the $19^{\text {th }}$ century A.D. were found in Çetinsu. In Sulakyurt 14 inscribed Molokan gravestones were discovered that should be dated to the end of $19^{\text {th }}$ and early $20^{\text {th }}$ centuries A.D. In the following sections major finds of these two seasons will be presented briefly.

\section{THREE TOWERS IN ÇEĞIILLİ (REVAS)}

The Village of Çeğilli (Revas) lies $16.5 \mathrm{~km}$ west of the city centre of Ardahan. Almost $2 \mathrm{~km}$ west of this village a tower structure has been found. A second tower has also been found at $500 \mathrm{~m}$ northeast of the first one. These finds are called as 'Çeğilli Towers 1 and 2' (Fig. 1a-b). A third one was discovered northwest of Çeğilli and called as 'Çeğilli Tower 3' (Fig. 1c). These towers were built with dry wall technique using regular cut big-sized basalt stones. According to their masonry they are similar to Late Bronze-Early Iron Age structures. In Çeğilli Tower 3 pottery of Bronze and Early Iron Ages and obsidian sherds were found.

\section{FORTIFIED HIGH PLATEAU SITE OF ÇEĞİLLi}

During the 2013 surveys a Bronze/Early Iron Ages archaeological site called as 'Büyük Tepe' has been found $600 \mathrm{~m}$ northeast of the Village Çeğilli. These remains are located on a terrace at the peak of Büyük Tepe with an altitude of $1970 \mathrm{~m}$ (Fig. 2). The residual mass consisted of embankment stones on the terrace of the hill and regular-cut large sized stones in small quantities have a radius about $16 \mathrm{~m}$. The stack of stones makes a circular form, indicates remains of a fortified settlement. Few pottery fragments have been documented essentially in the northeast and southern slopes and on the peak of the hill, but it is difficult to suggest an exact date for them. At the same time on northwest slope of the hill some obsidian fragments are encountered. An archaeological excavation is necessary to comprehend the function of the remains and to date them accurately.

\section{YOKUŞDİBİ (LORI) FORTRESS (?)}

Some field researches were done in Yokuşdibi (Lori) Village and its surroundings which is located in $13 \mathrm{~km}$ northwest of the city centre of Ardahan. A fortress or a site was identified which seems to have Bronze Age characteristics ${ }^{7}$. Remains of Yokuşdibi have been ascertained on a ridge which lies about 2 $\mathrm{km}$ north of the village centre and $1 \mathrm{~km}$ south of Artvin-Ardahan highway, on an altitude of $2105 \mathrm{~m}$. In the centre of the remains an almost square planned tower structure with dimensions of $12 \times 13.5 \mathrm{~m}$ lies along the northeast-southwest direction. The distance between the inner and outer walls of the tower that was built with large sized basalt stones in dry wall technique, varies from $1.70 \mathrm{~m}$ to $2.20 \mathrm{~m}$. Beginning from few meters outside the northeastern edge of the tower and extending along the southwest-northeast direction, remains of another wall with almost $20 \mathrm{~m}$ length and about $2 \mathrm{~m}$ width were found (Fig. 3). Furthermore, $25 \mathrm{~m}$ south of this place, there are possible traces of a fortification wall extending around 50-60 $\mathrm{m}$ in east-west direction in a scattered state. Numerous pottery finds have been documented on the same level with these remains. 


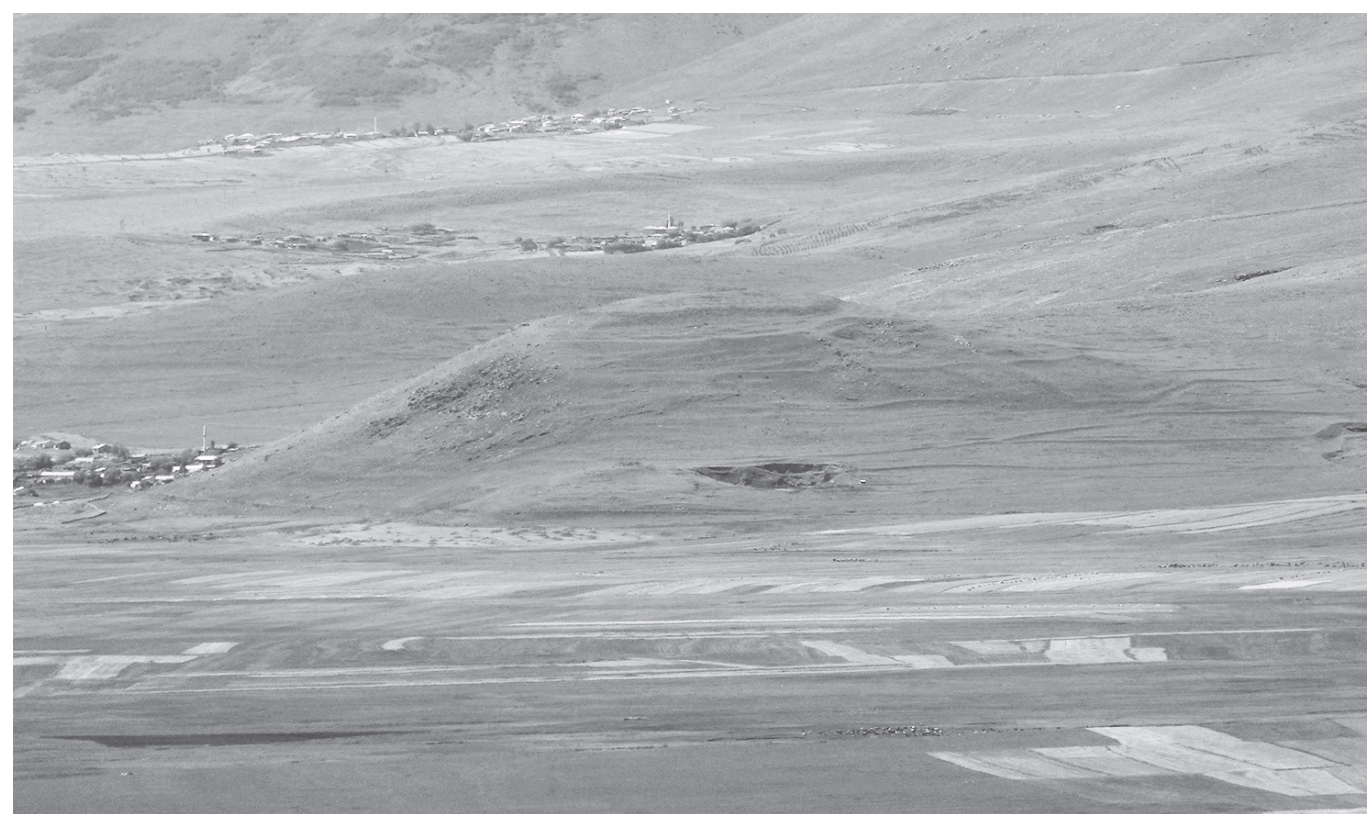

Fig. 2 : Fortified high plateau site of Çeğilli; view from the east (S. Patac1, 2013).

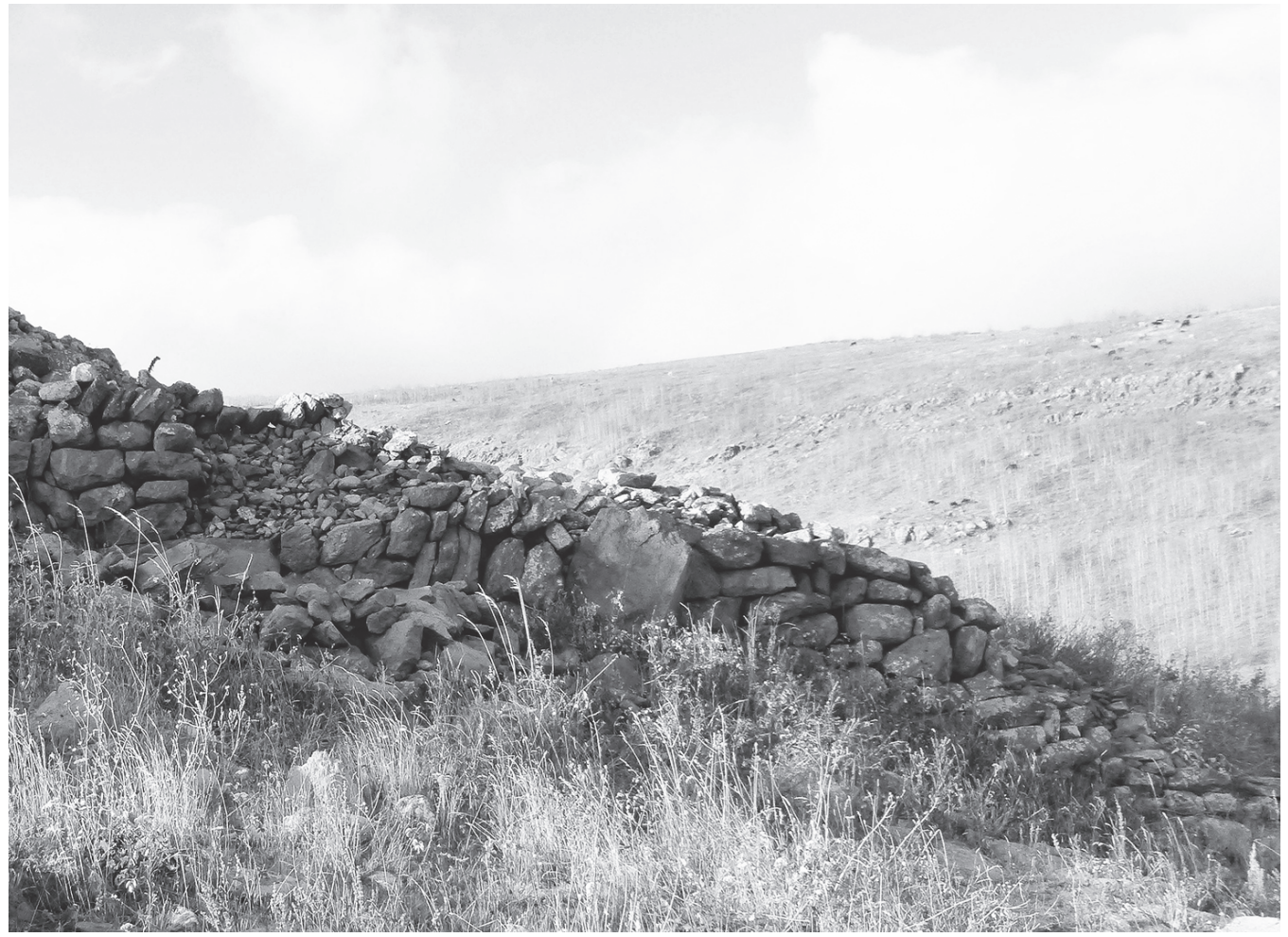

Fig. 3 : Yokuşdibi Fortress; view from the northeast (S. Patacı, 2013). 


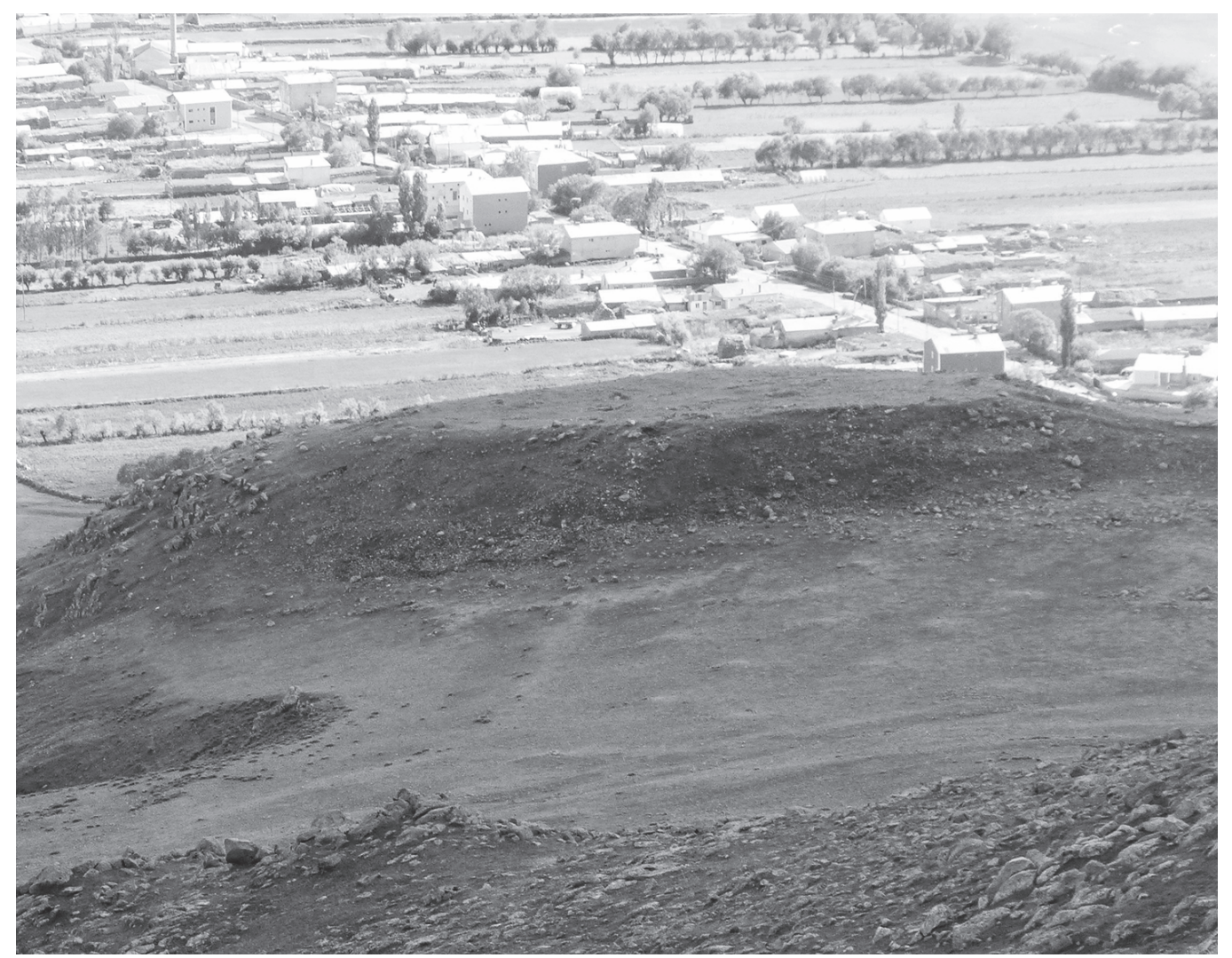

Fig. 4 : Bronze Age site of Sulakyurt; view from the north (S. Patac1, 2014).

\section{BRONZE AGE SITE OF SULAKYURT (SARZEP)}

Sulakyurt (Sarzep) is situated $9.5 \mathrm{~km}$ northwest of the Ardahan city centre and this site can be reached via Artvin-Ardahan highway. A very little site located 300-400 m northeast of Sulakyurt Village with an altitude of $1987 \mathrm{~m}$ has been called as 'Bronze Age Site of Sulakyurt' (Fig. 4). The peak of this site is $c a .70 \times 40 \mathrm{~m}$, is in the form of a natural terrace. There are remains of a wall surrounding this terrace. Numerous pottery sherds from this terrace belong to the Bronze Age (Fig. 5) whereas a small portion of sherds may belong to the Early Iron Age. In almost all parts of the site obsidian fragments were documented which was the largest assemblage of the site.

\section{FORTIFIED HIGH PLATEAU SITE OF SULAKYURT (SARZEP)}

Archaeological remains of an high plateau site has been discovered at an altitude of $2125 \mathrm{~m}$ at the southward peak of a mountain, 850-900 m north of Bronze Age site of Sulakyurt (Fig. 6). A tower is located on the terrace of the mountaintop (Fig. 7).
Large and small sized stones had been used in this tower which was built in dry wall technique. Some further wall remains must belong to a terrace wall and to other types of structures (Fig. 8-9). In an area of about $75 \mathrm{~m}$ around the tower a small amount of pottery fragments of the Bronze Age and possibly Early Iron Age has been documented. It seems that an archaeological excavation is the only option to figure out when the site was really in use and if there was a relationship between this high plateau site and the Bronze Age site of Sulakyurt which is located just $900 \mathrm{~m}$ south of it.

\section{FORTIFIED HIGH PLATEAU SITE OF DEĞİRMENLİ AND A CIRCULAR MONUMENT}

Değirmenli Village which is located $13 \mathrm{~km}$ northwest of the city center of Ardahan lies between Yokuşdibi and Sulakyurt sites. Some archaeological remains on a hill called as 'Ziyaret Tepe' were discovered $1.3 \mathrm{~km}$ southeast of this village. There are three staged terraces on Ziyaret Tepe (Fig. 10). A tower structure is located at the center of the uppermost terrace of the hill (Fig. 11). Architectural posture of this tower does not differ from the other 

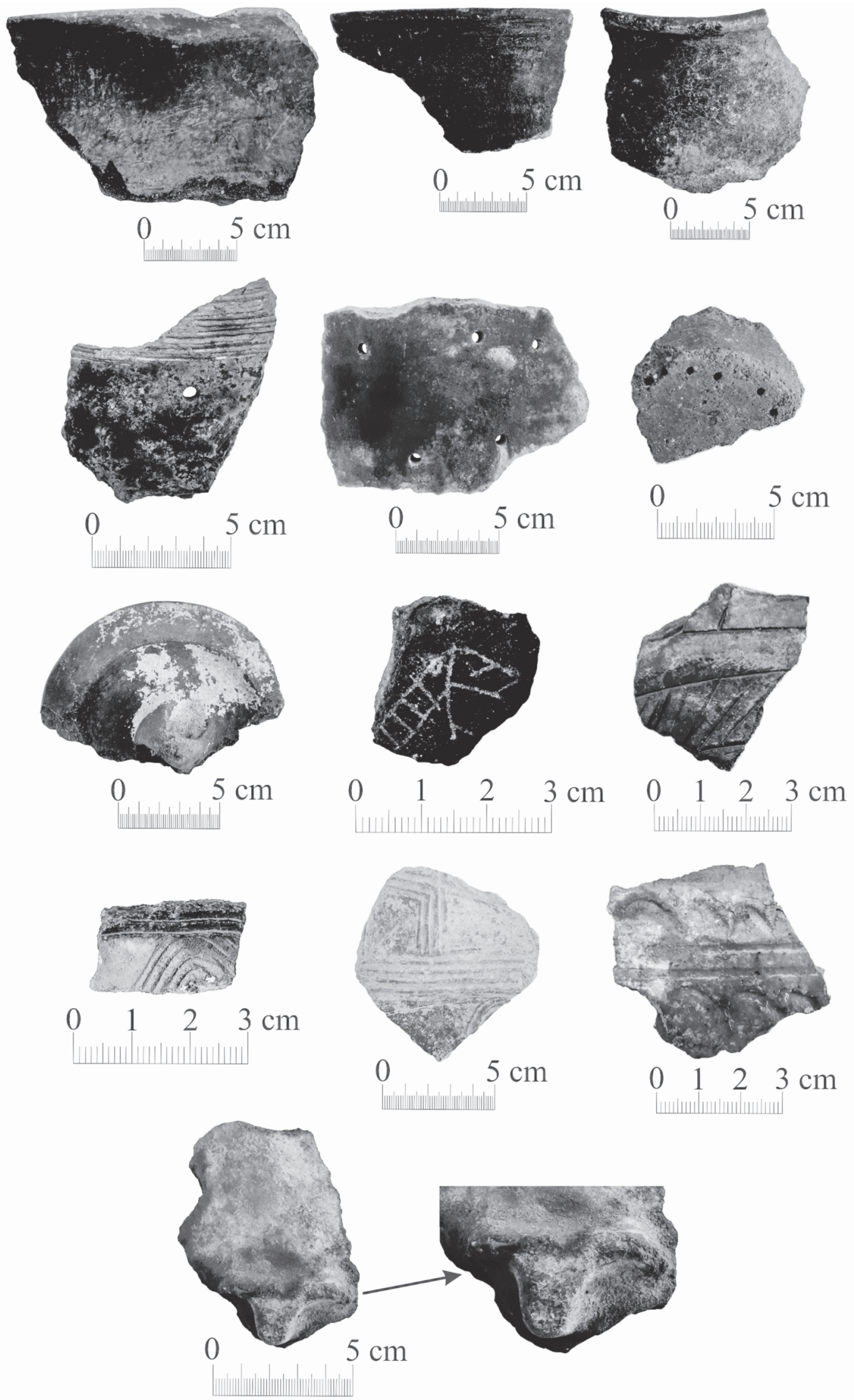

Fig. 5 : Pottery finds from the Bronze Age site of Sulakyurt (S. Patac1, 2014). 


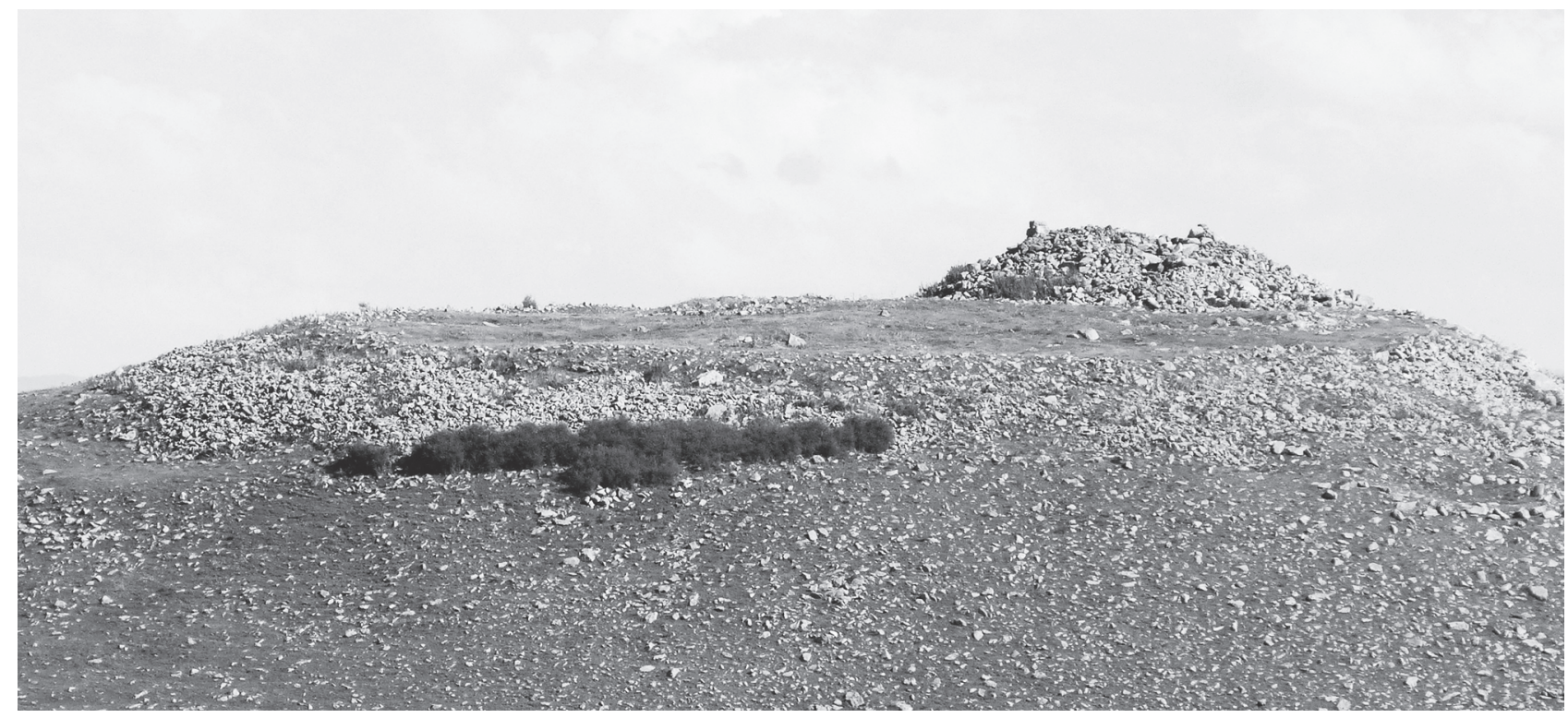

Fig. 6 : High plateau site of Sulakyurt; view from the northwest (S. Patac1, 2013).

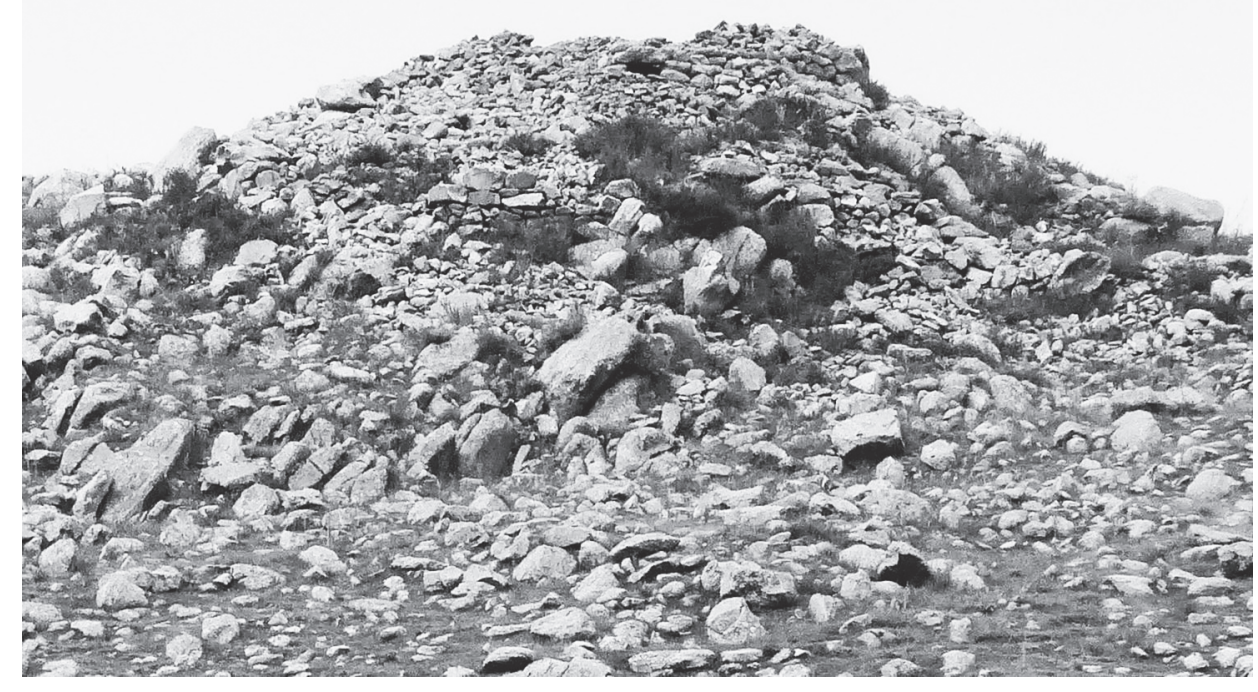

Fig. 7 : A tower of the fortified high plateau site in Sulakyurt (S. Patac1, 2013).

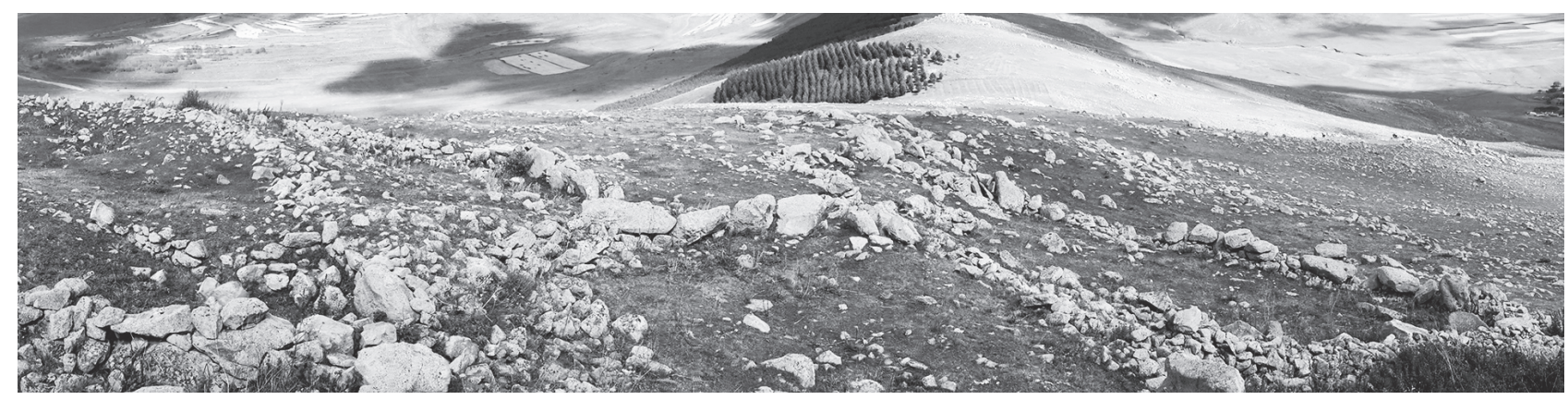

Fig. 8 : Architectural remains of the high plateau site of Sulakyurt (S. Patac1, 2013). 

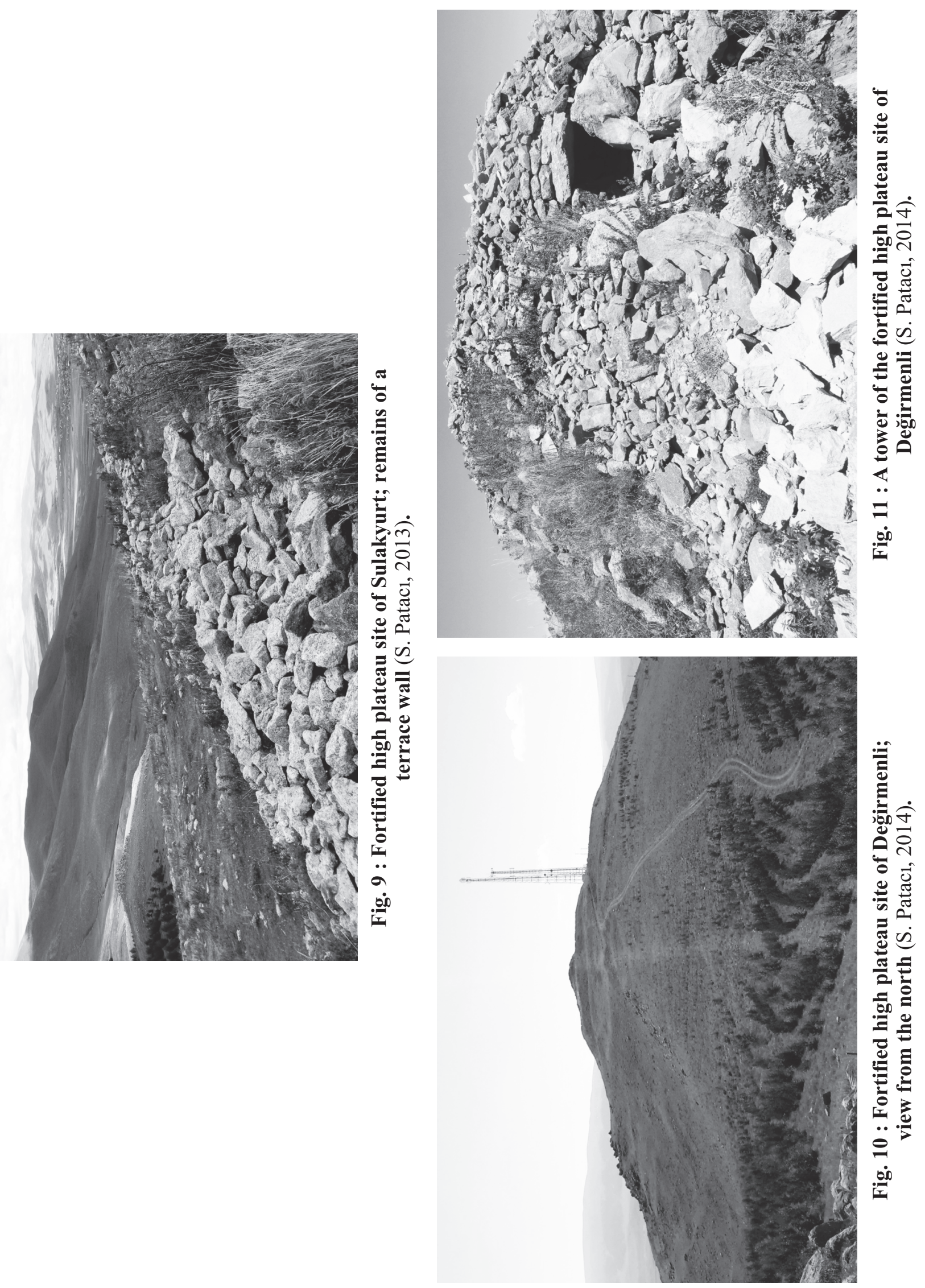


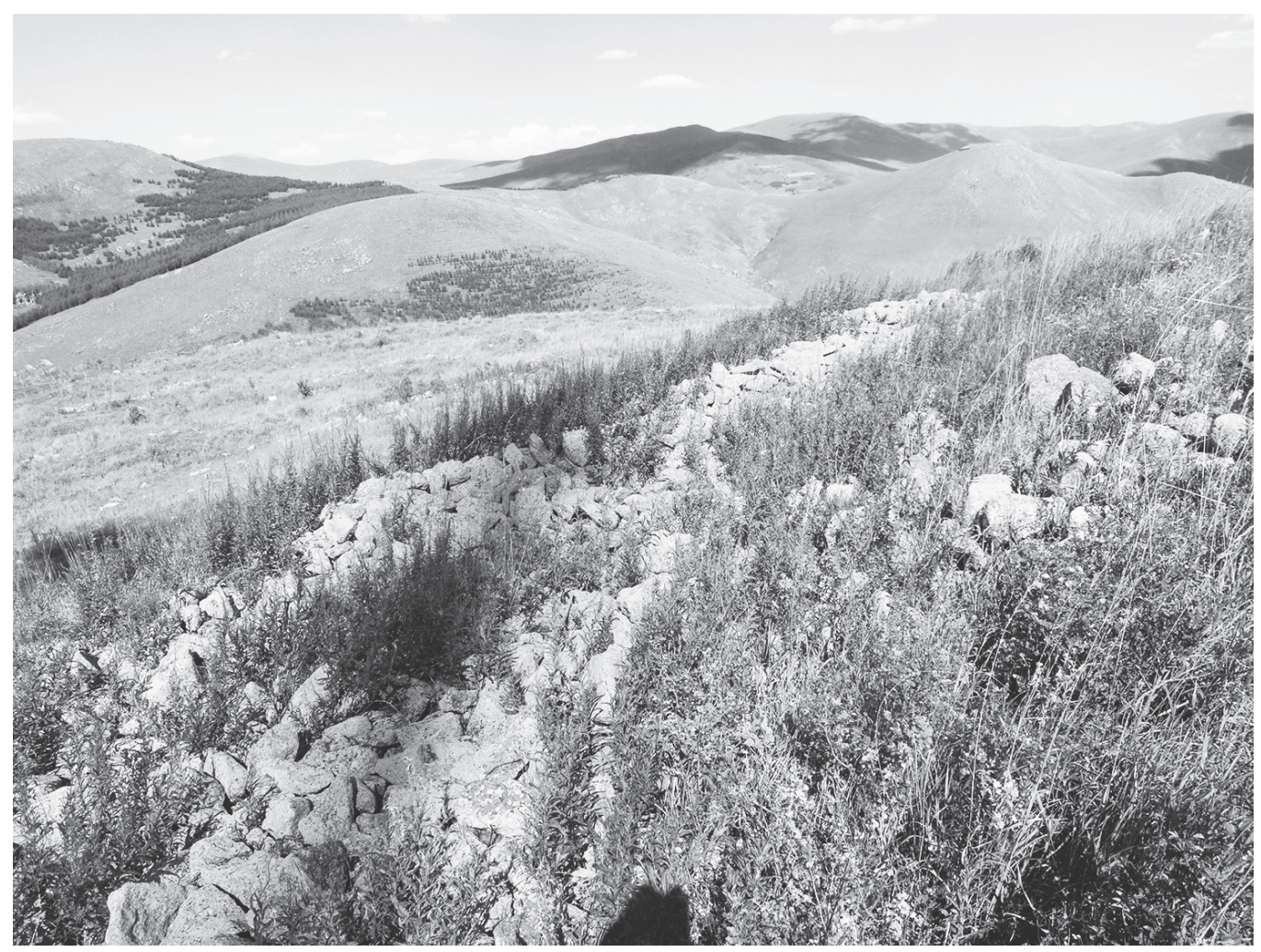

Fig. 12 : High plateau site of Değirmenli; remains of a fortification wall (S. Patac1, 2014).

towers around the region. It was built in dry wall technique and it has a nearly rounded plan. There are two entrances in different levels in the southern part of the tower. At the same time there are two varying fortification wall remains which surround this tower in different levels (Fig. 12). A large portion of Early and Middle Bronze Age pottery and obsidian sherds are documented.

A circular monument is located on the southern slope of Ziyaret Tepe and $360 \mathrm{~m}$ south of the high plateau site of Değirmenli. Dimension of this area with the monument is $45 \times 37 \mathrm{~m}$. Walls of the monument were almost completely damaged. No pottery has been found which makes it difficult to date this monument. The function of this monument is not clear; perhaps it was used as a settlement or a sheepfold during the Bronze or Early Iron Ages.

\section{ARCHAEOLOGICAL FINDS AT ATTEPE}

Çataldere Village (Kundzeti) is located $16 \mathrm{~km}$ northeast of the city center of Ardahan. During the surface surveys around this site an archaeological unit was discovered at a peak of a hill called 'Attepe' which is $1.6 \mathrm{~km}$ northeast of Çataldere. It covers a terraced area of $60 \times 40 \mathrm{~m}$. Remains of a wall surround this terrace and an ellipse-shaped monument has been found be on the ground level inside the northern part of the terrace (Fig. 13). This archaeological place is just across the Kunzut Fortress which is located on the north and was studied by K. Köroğlu in $1997^{8}$. Attepe could be used as a watchtower. A sheepfold or a high plateau site also seems to be possible. Unfortunately no pottery or other type of small finds were found.

\section{FORTIFIED BRONZE AGE SITE AND CEMETERY OF KARTALPINAR (FAHRER)}

Kartalpınar Village is situated 7-8 km north of the city center of Ardahan and it has been surveyed in 2014 campaign. There is a Bronze Age site and a cemetery $1.2 \mathrm{~km}$ northeast of Kartalpinar'. This archaeological area is only 170 m north of Kura River at $1827 \mathrm{~m}$ of altitude (Fig. 14). The size of the site is $88 \mathrm{~m}$ at east-west direction and $63 \mathrm{~m}$ at north-south. The site has two main parts in the north and south. The southern part was also separated in two sections

8) Köroğlu 1999: 148.

9) Patac1 and Lafl1 2015a. 


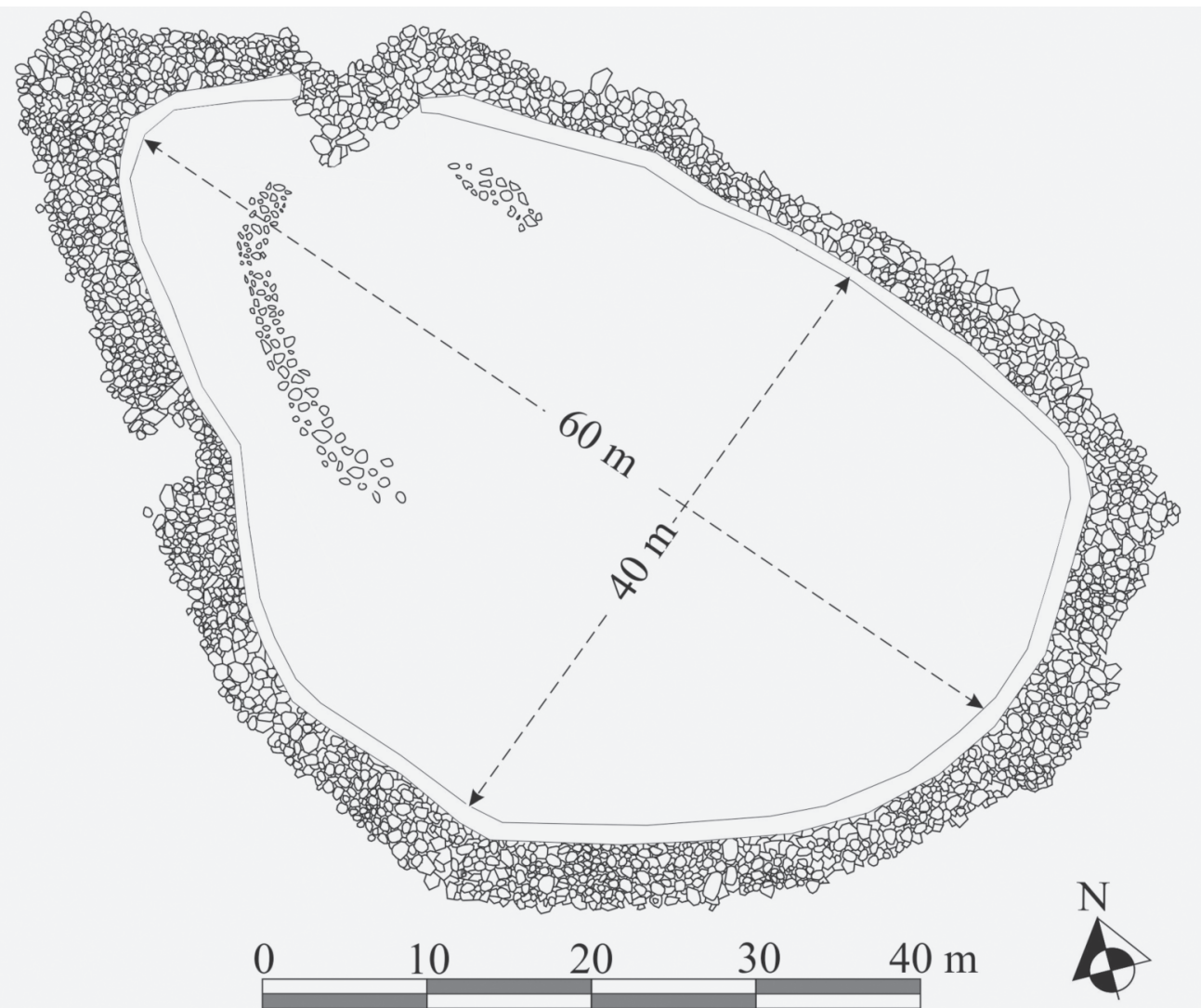

Fig. 13 :

Plan of Attepe

(S. Patac1, 2014).

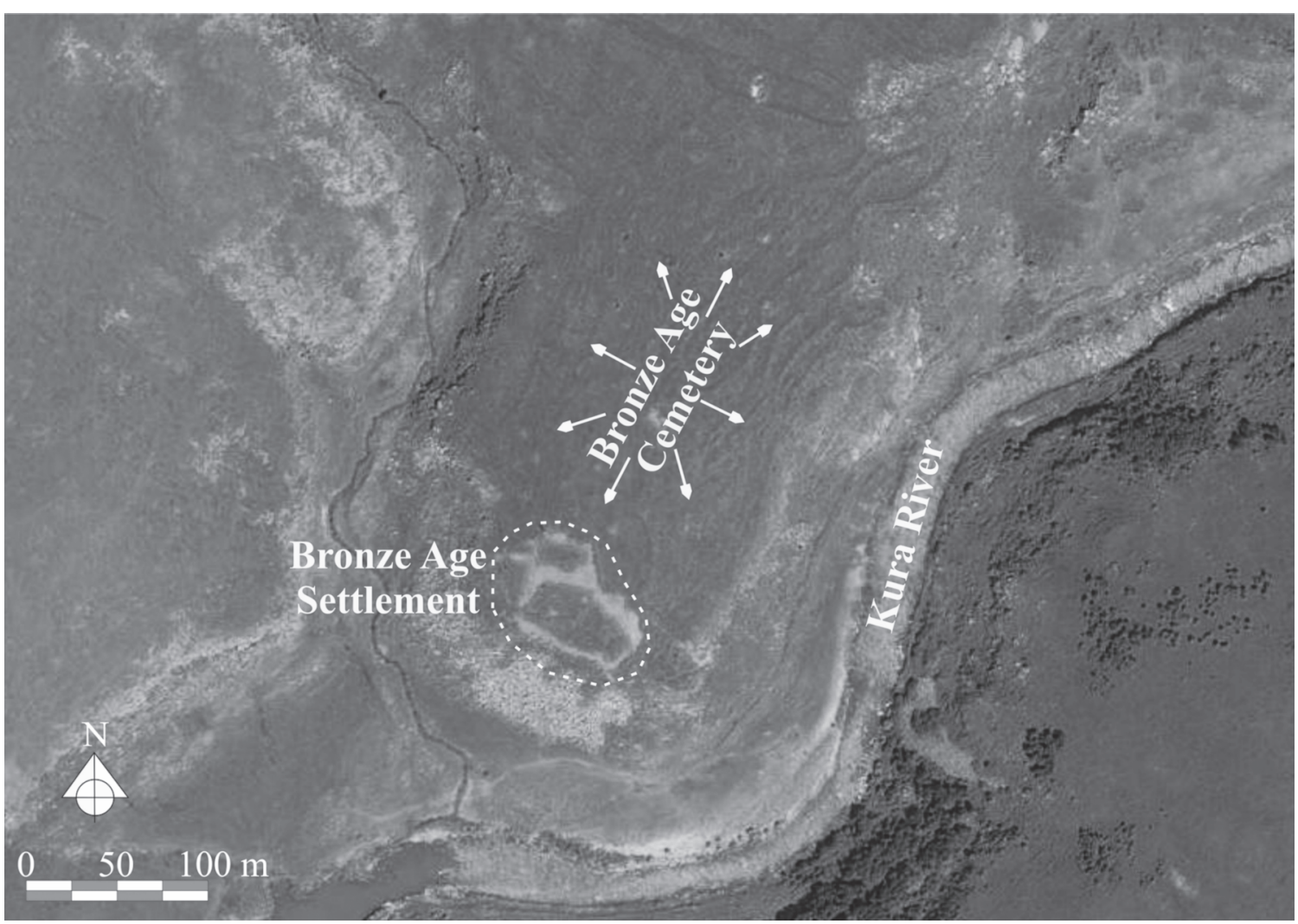

Fig. 14 : Aerial photograph of the Bronze Age site and cemetery of Kartalpınar (S. Patac1, 2014). 


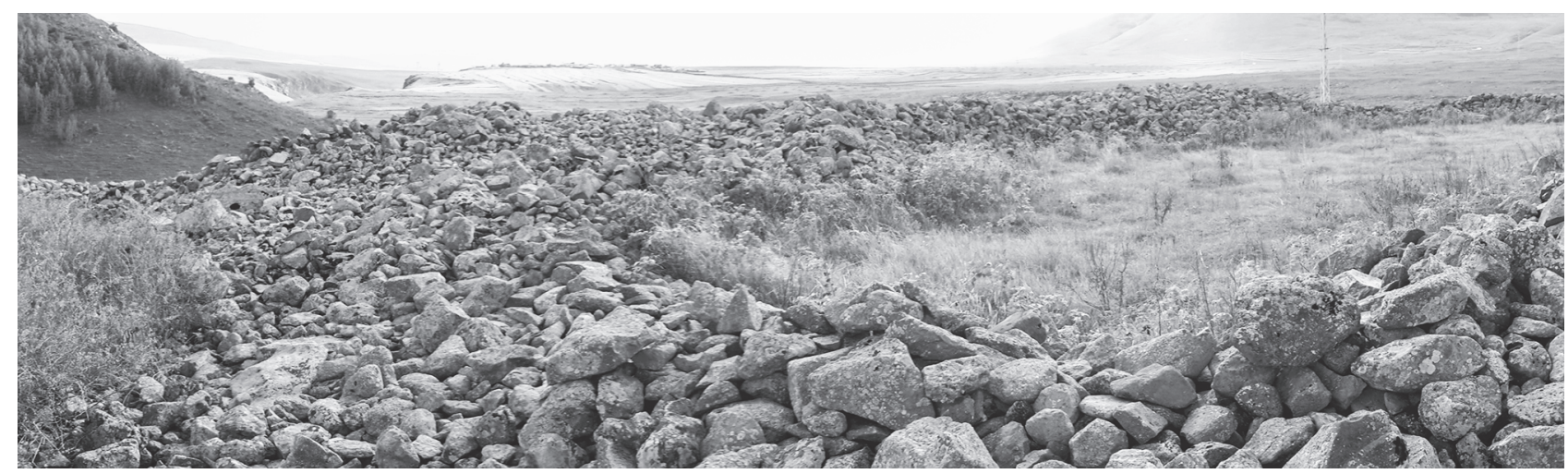

Fig. 15 : Bronze Age site of Kartalpınar (S. Patac1, 2014).

by a wall at north and south directions. The walls of the site were built with dry wall technique using large and small sized stones. Piles of stones which belong to the walls of the site are spread over the ground (Fig. 15). This area must had been used as a fortification. Its close position to Kura River makes it an appropriate location for a possible protohistoric site. A small amount of Bronze Age ceramic and obsidian fragments are found around the site.

A Bronze Age cemetery, located just north of Kartalpinar Site has been found and is 75/100 x $65 \mathrm{~m}$ (Fig. 14). This cemetery is one of the largest Bronze Age cemeteries in eastern Anatolia. Numerous Bronze Age pottery and obsidian sherds are documented (Fig. 16). Some of the tombs are unearthed by recent illicit excavations (Fig. 17). It is possible that some of the graves had been built in kurgan $^{10}$ type.

A nearly rectangular monument is located 800 $m$ northeast of Kartalpınar site and cemetery which lies in east-west direction with the dimensions of 70 x $33 \mathrm{~m}$ and was built in dry wall technique. Nevertheless, there is not much left from it and no pottery sherds have been found to suggest a date for it.

\section{MEDIEVAL ARCHAEOLOGY IN ARDAHAN}

In 1977 and 1983 R. W. Edwards, has organized two expeditions to Erzurum, Artvin and Ardahan and their neighbourhood to inspect Medieval architectural remains ${ }^{11}$. A second researcher in the area was an Austrian, B. Baumgartner, who had surveys in Tao-Klarjeti in 1980s and in the year of 1990, and studied the surface evidence of the Medieval Georgian architecture $^{12}$. A project focused on Medieval Georgian architecture at Tao-Klarjeti zone has been carried out by M. Kadiroğlu ${ }^{13}$ between 1996 and 2005; thereafter the project has resumed by F. Bayram ${ }^{14}$. At the beginning in the project two Turkish provinces, Artvin $^{15}$ and Erzurum, were included; then Ardahan was also incorporated. Numerous Georgian religious architectural examples were examined based on ob-

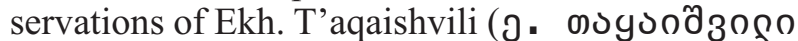
in Georgian; 1863-1953), a Georgian historian, archaeologist and public benefactor who organized a series of archaeological expeditions to the historic Georgian region of Tao-Klarjeti ${ }^{16}$ and wrote numerous scholarly works on the history and archaeology of Georgia and the Caucasus which are of special value even today. In the survey campaigns of 2013 and 2014 several Medieval sites and monuments in central district of Ardahan were documented: A Medieval church in Yalnızçam (Sindiskom) district, four chapels in Çetinsu (Beberek), Yokuşdibi (Lori), Sulakyurt (Sarzep) and Kartalpınar (Fahrer) villages, and a possible bath in Kartalpınar ${ }^{17}$. The church at Yalnızçam was built in infill wall technique with basalt stones and architecturally it is a typical Medieval Georgian church of $10^{\text {th }}-12^{\text {th }}$ centuries (Fig. 18). In the city center of Ardahan single-naved chapels had been substantially destroyed apart from

10) 'Kurgan' is the Russian word of Turkic origin for tumulus; with its use in Soviet archaeology the word is now widely used for tumuli in the context of Transcaucasian and Central Asian archaeology.

11) Edwards 1986: 165-182; 1988: 119-141.

12) Baumgartner 2009: 183-187.

13) Kadiroğlu-Leube, Yazar and Karaca 1997: 397-421; Kadiroğlu-Leube 1998; 97-125; Kadiroğlu 1999: 8-19; 2000: 81-86; as well as Kadiroğlu et al. 2005: 93-106.

14) Bayram and Yazar 2008: 263-284; 2011: 1-18; 2013: 321-336.

15) Bayram 2005.

16) T'aqaishvili $1909 ; 1924 ; 1938$.

17) Patacı and Oral 2015. 

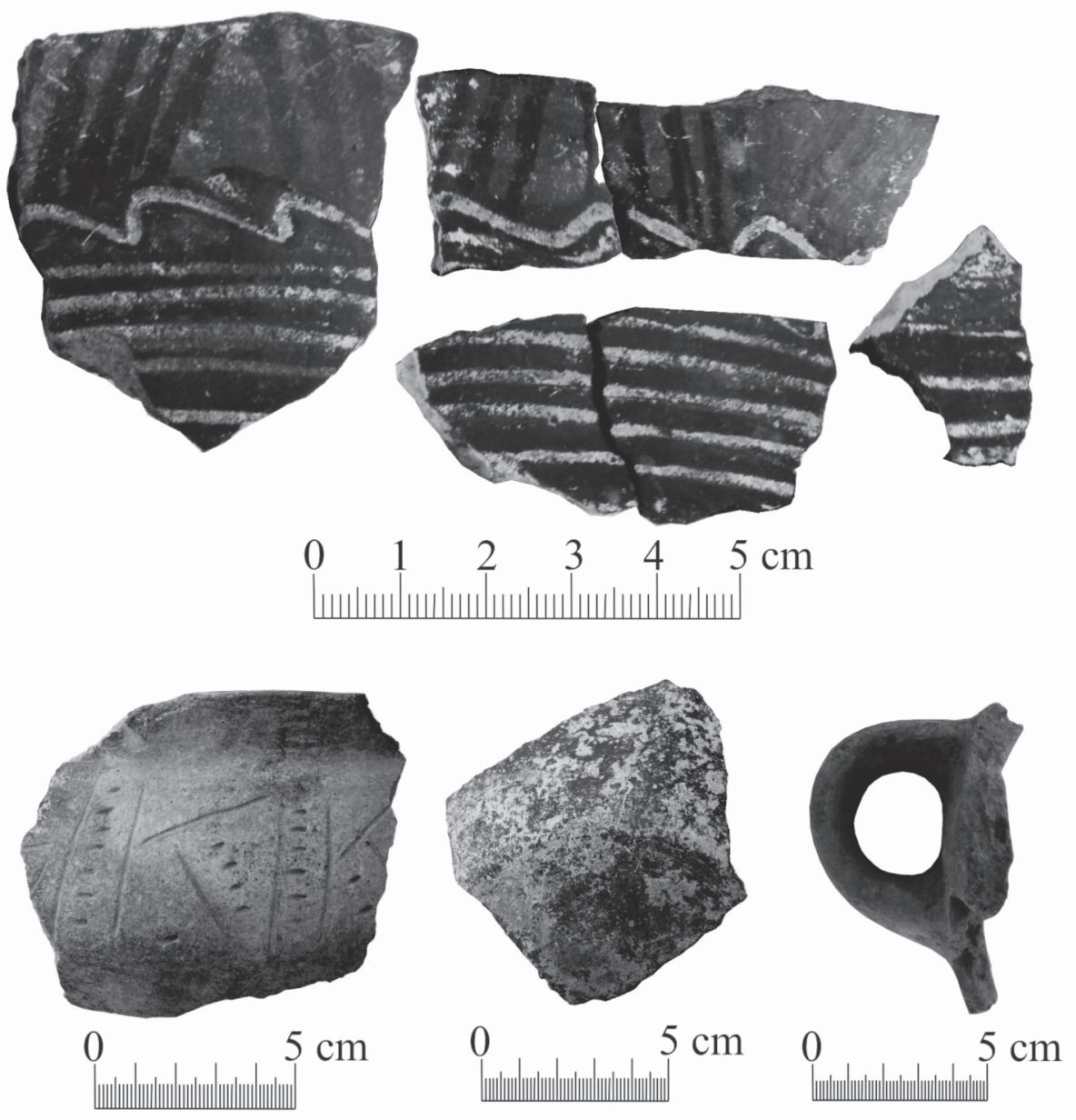

Fig. 16 : Pottery finds from Kartalpınar cemetery (S. Patac1, 2014).

Fig. 17 : A grave found by illicit excavations at Kartalpınar cemetery (S. Patac1, 2014).

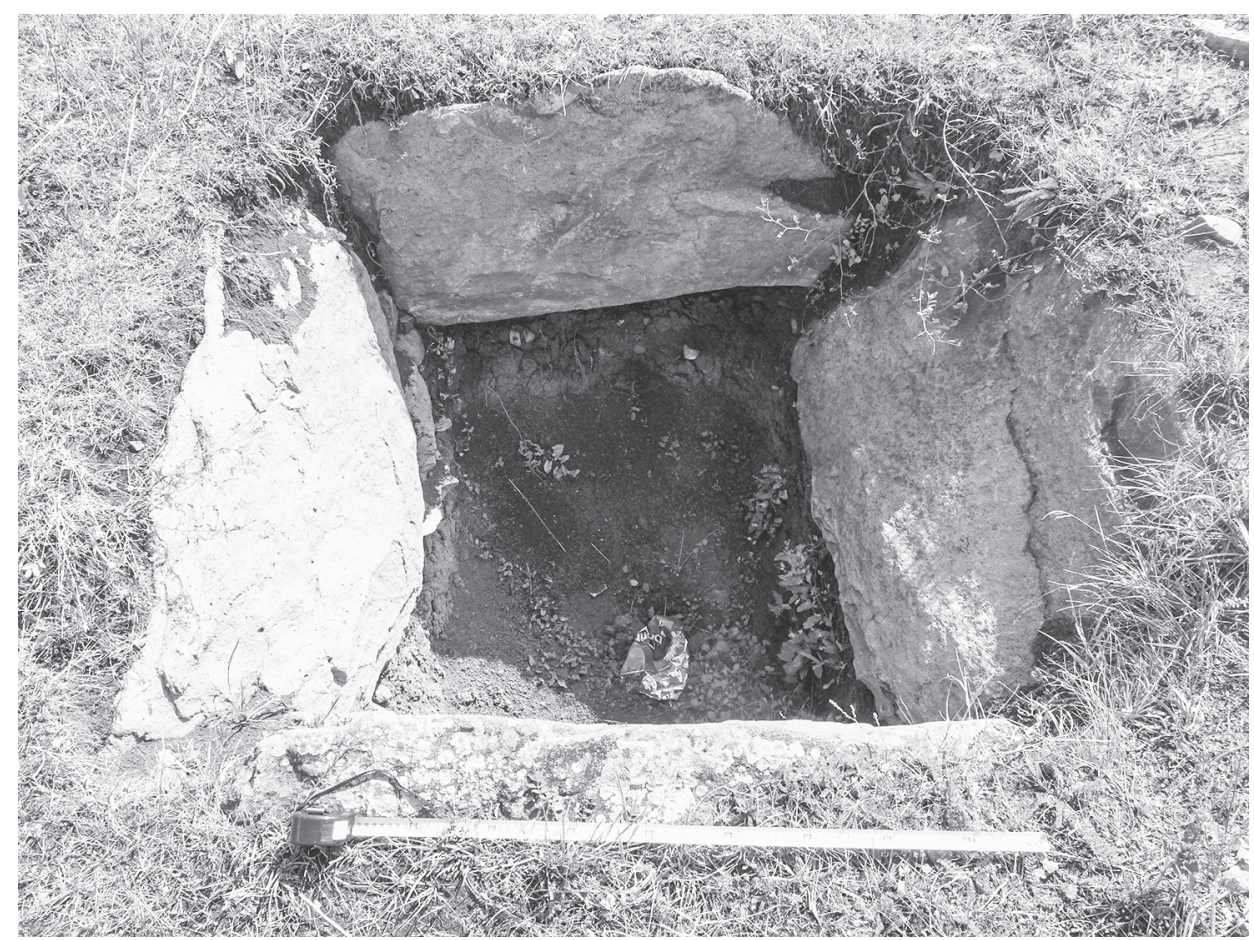


the one in Çetinsu (Fig. 19) which demonstrates characteristics of the Medieval Georgian religious architecture. The bath/residence in Kartalpınar village (Fig. 20) seems to be the only Medieval civic architectural example that was discovered during our researches. A chapel located $30 \mathrm{~m}$ north of this building makes us to think that there had been a functional relationship between these two buildings.

A re-used Medieval ( $9^{\text {th }}-10^{\text {th }}$ centuries) Georgian inscription is discovered on the fortification wall of Ardahan Fortress which was built in the city centre during Turkish-Islamic period (Fig. 21). This fourlined inscription by local limestone, located on inner facade of north fortification wall of the fortress is approximately 3 meters above from ground level and made by volcanic tuff. The inscription is in a rectangular frame of $45 \times 31 \mathrm{~cm}$. Height of each letters ranges between 3 and $8,5 \mathrm{~cm}$. Translation of this inscription is as follows:

\section{Sacred \\ stone. \\ Jacop's \\ rock.}

Although we cannot judge about the function of this very short inscription, it is probable that this stone was obtained from a religious structure around the area during the building of the fortress.

Another Georgian inscription is found in a small village, called 'Kumlukoz' in Posof district of

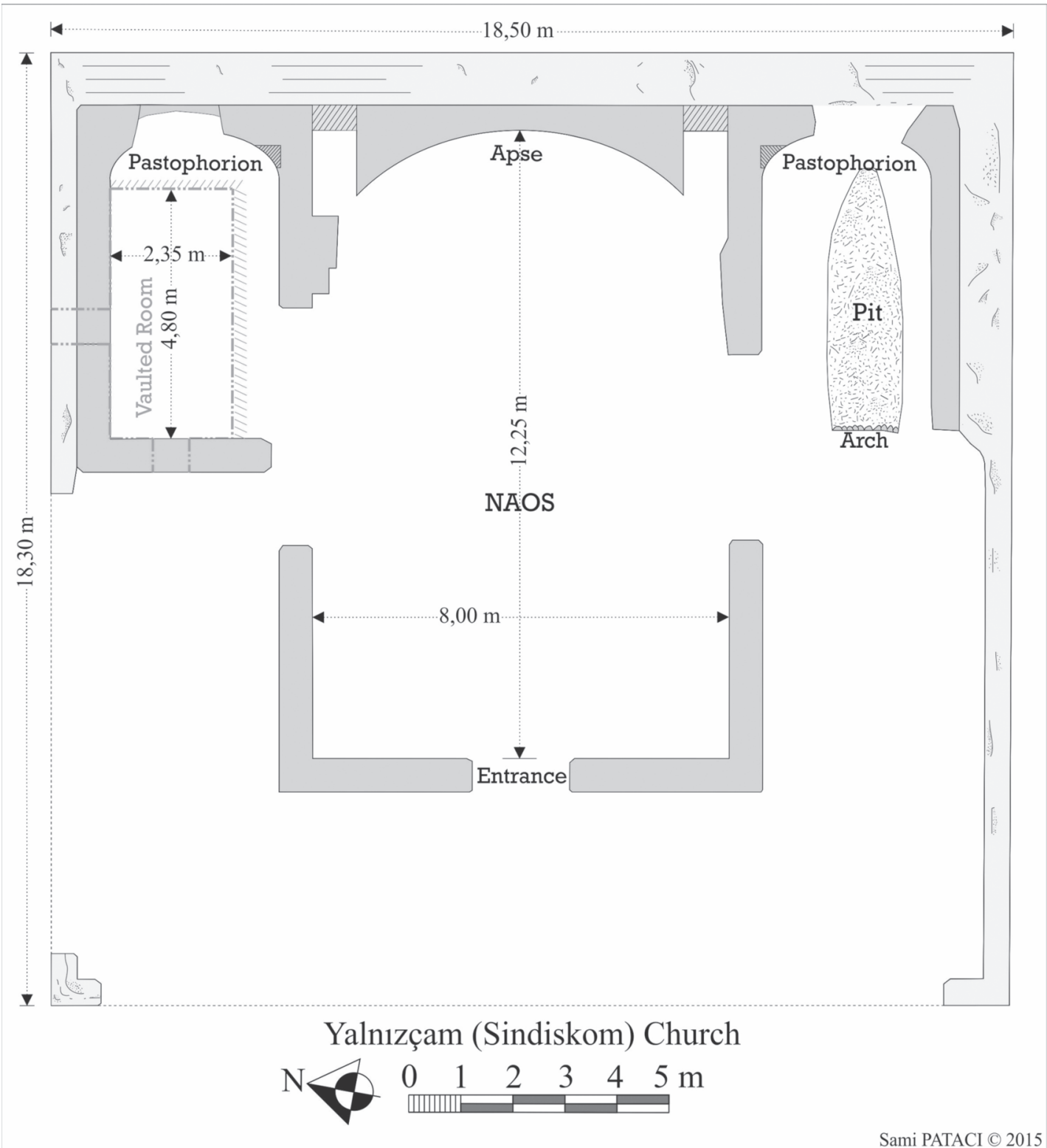

Fig. 18 : Plan of the Yalnızçam (Sindiskom) Church (S. Patac1, 2014). 


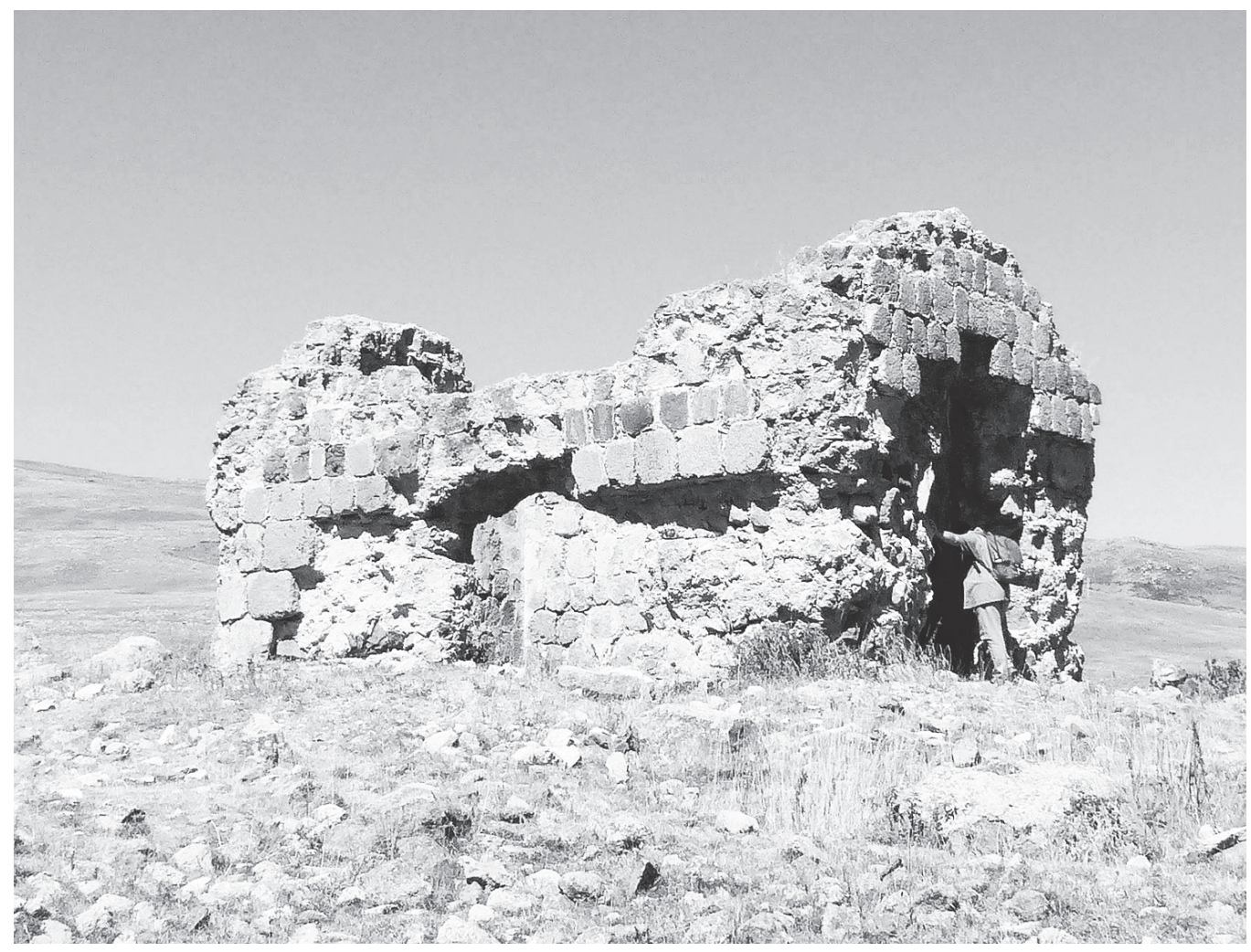

Fig. 19 : Chapel at Çetinsu (Beberek); view from the southeast (S. Patac1, 2014).

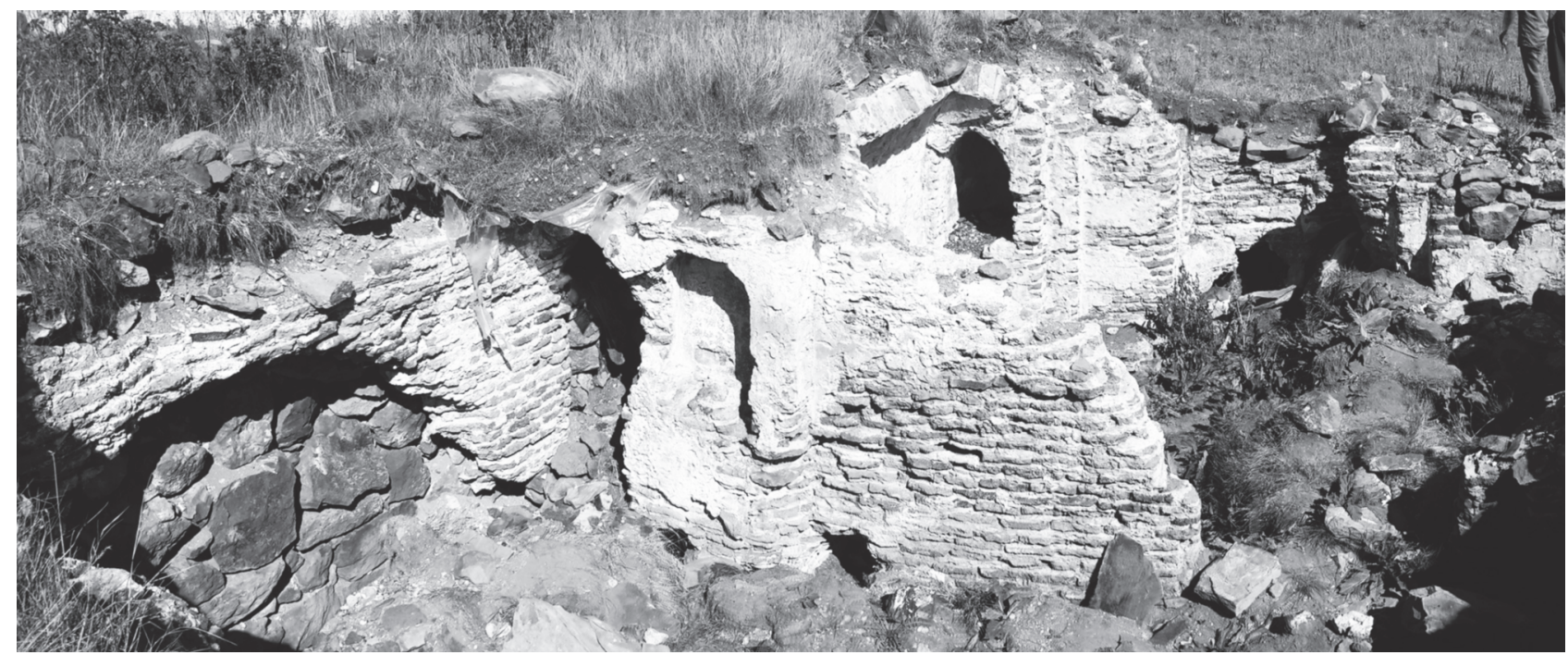

Fig. 20 : A Medieval bath/residence from Kartalpınar (S. Patac1, 2014). 


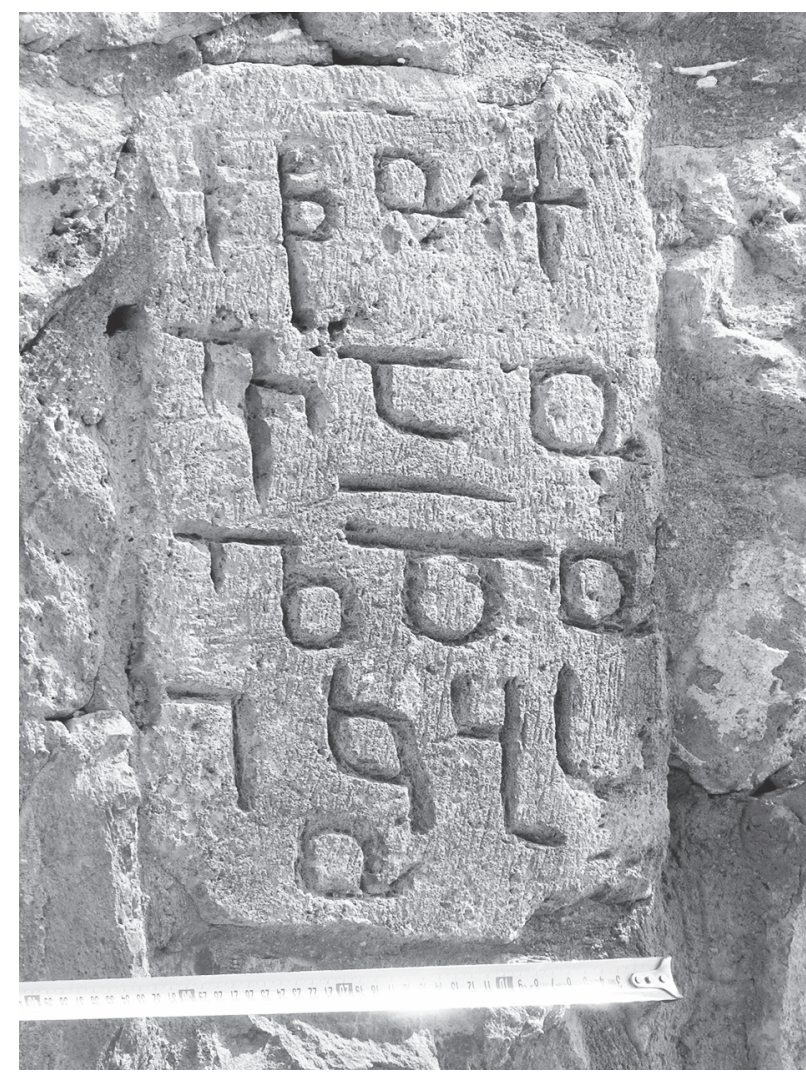

Fig. 21 : A Medieval Georgian inscription from the fortress at Ardahan (S. Patac1, 2014). dated to the $10^{\text {th }}-12^{\text {th }}$ centuries; but for the date of the epitaph a more detailed study is needed. It was engraved on a limestone stele which is used as a stair in front of a house (Fig. 22). The stele was surmounted by a cross which was fixed at the top. Transcription and translation of the epitaph are as follows:

$$
\begin{aligned}
& \text { „m(39ogm)m, | } \quad \text { a(gm)b | }
\end{aligned}
$$

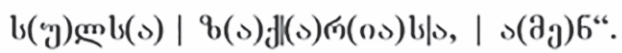

\author{
God, have mercy \\ upon the soul of Zakaria, amen ${ }^{18}$
}

\section{POST-MEDIEVAL ARCHAEOLOGY IN ARDAHAN}

The region of Ardahan on the Turkish-Georgian borderline is significant for its archaeological heritage of Molokans (in Russian 'молокане' for 'milkdrinkers'), members of a Christian sect that evolved from 'Spiritual Christian' Russian peasants who refused to obey the Russian Orthodox Church. At the end of the $19^{\text {th }}$ century there were about 500,000 Molokans within the Russian Empire. Before World War I there was a well-known colony of Molokans

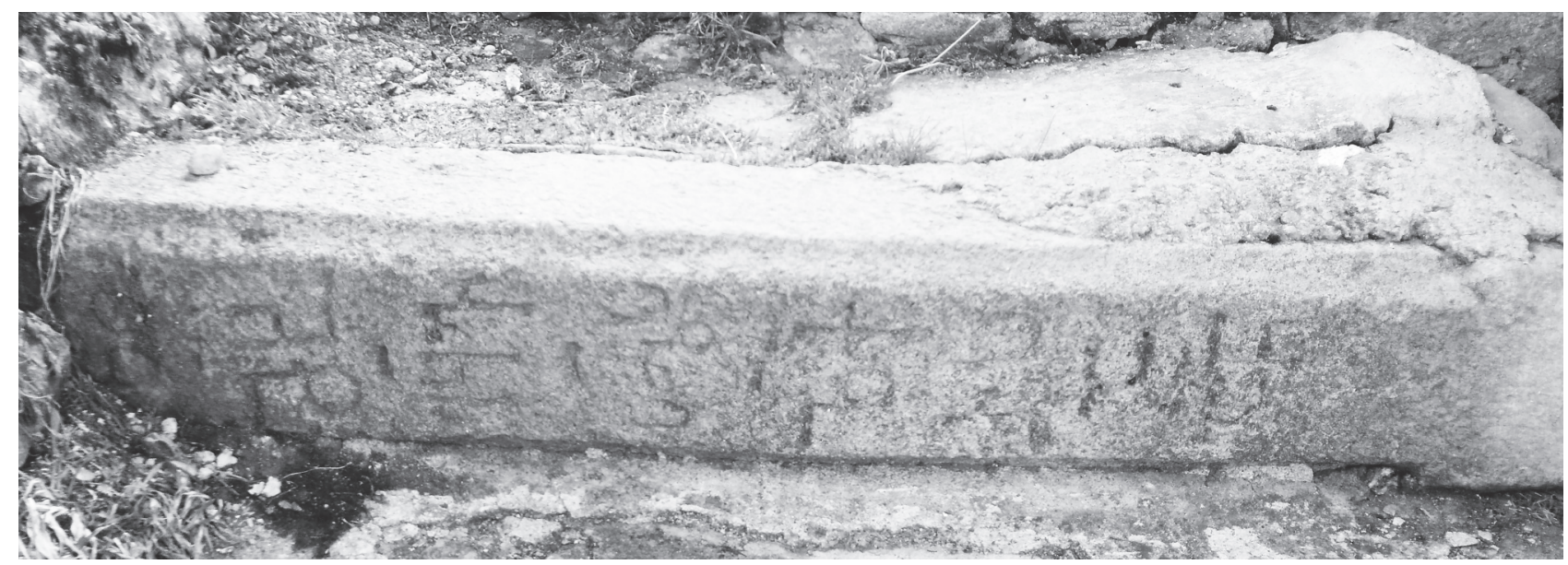

Fig. 22 : A Georgian inscription from Kumlukoz (S. Patac1, 2015).

Ardahan and it is a funerary text. Kumlukoz village was one of the Georgian settlements in the region and its original name was 'Gume' that must be associated with the Georgian word 'Gwime'. In this village there is a Medieval chapel which must be that had been exiled to the Caucasus, an area long within Russian hegemony, mainly to what is now Georgia, Armenia, Azerbaijan, and northeastern Turkey, i.e. Kars and Ardahan. During the field surveys in 2013, 14 Molokan inscribed gravestones

18) We would like to thank to Assoc. Prof. Teimuraz (Temo) Jojua and Mr. Lado Mirianashvili for their assistance in transcription and translation of this epitaph. 


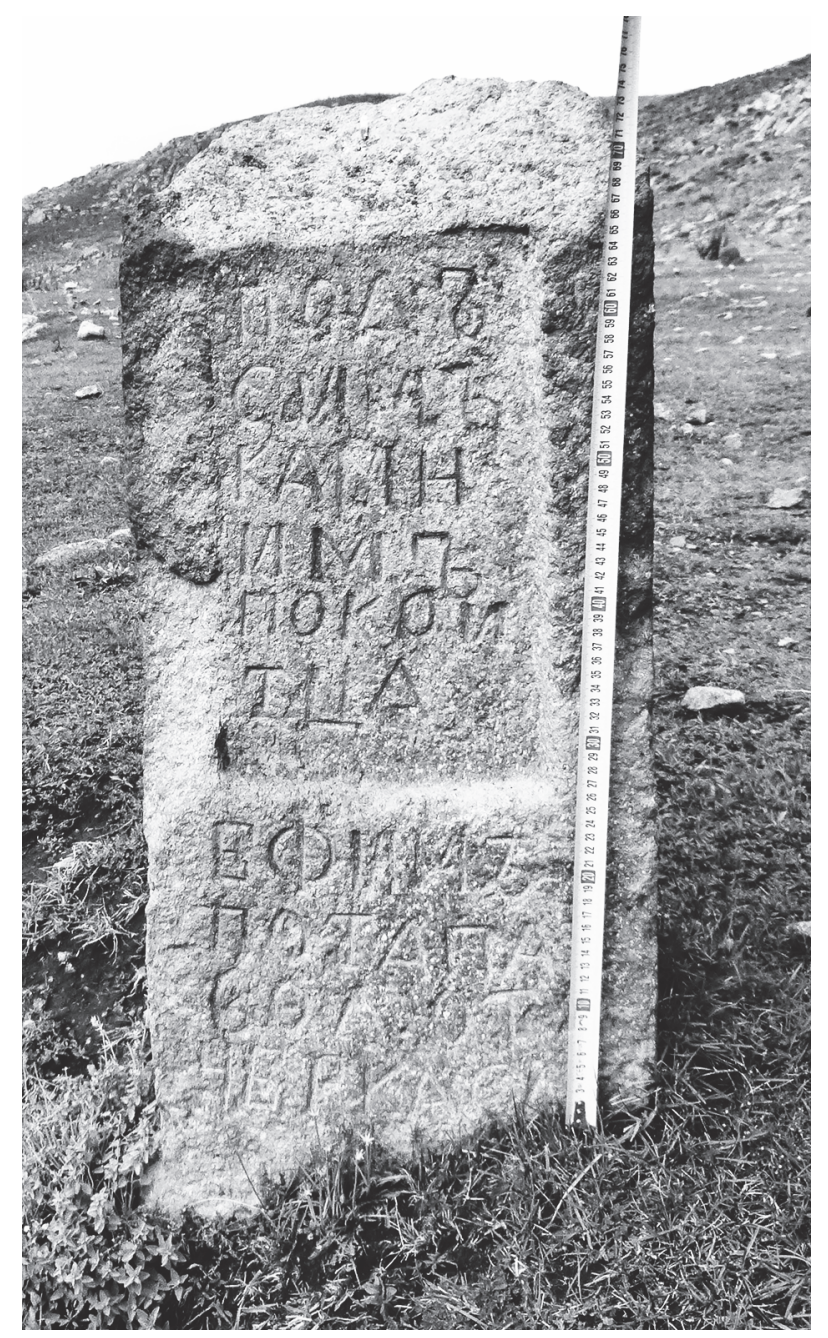

Fig. 23 : A Molokan inscription from Sulakyurt; late $19^{\text {th }}$ cent. A.D. (S. Patac1, 2014).

in Sulakyurt and three Greek inscribed gravestones in Çetinsu Villages were documented (Fig. 23-24). These Molokan gravestones are the archaeological evidences of the Molokan exiles to the region after the Russo-Turkish War of $1877-1878^{19}$.

\section{CONCLUSION}

The main subject for the field surveys in Ardahan in 2013 and 2014 was the Bronze Age sites of high plateau people whose daily bread was livestock ${ }^{20}$. It is obvious that usual höyük sites of the Bronze Age are not many in our survey area and our main settlement pattern in Ardahan is Bronze Age sites or

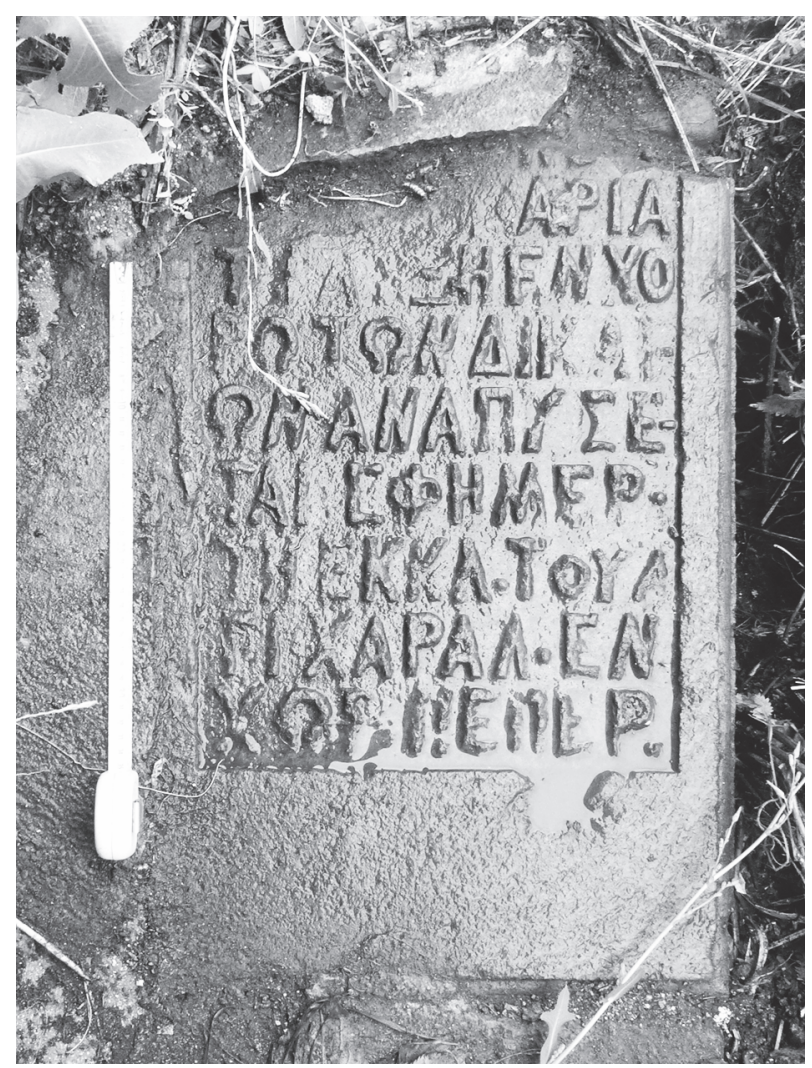

Fig. 24 : A Greek inscription from Çetinsu; late $1^{\text {th }}$ cent. A.D. (S. Patac1, 2014).

shelters of high plateau people on mountaintops which seem to be a unique feature for this part of eastern Anatolia.

The first extensive researches about the pottery traditions in eastern Anatolia were the studies of A. Çilingiroğlu in the basin of Lake Van ${ }^{21}$. Short-termed studies of the Chalcolithic and Early Bronze Age pottery by C. A. Burney in 1956 is significant for the northeastern Anatolian cities ${ }^{22}$. So far the pottery tradition of the high plateau culture in $2^{\text {nd }}$ Millennium B.C. was clarified mostly by the finds from burial sites and limited numbers of settlements. Our surveys in Ardahan provided further examples of alreadyknown pottery types of the Bronze Age from the settlements as well as a few of Karaz pottery ${ }^{23}$.

The discovery of the Bronze Age cemetery site of Kartalpınar in the central district of Ardahan was the most important contribution to Transcaucasian archaeology of the region. Although recent researches

19) Patacı and Küçük 2015; as well as Patacı and Laflı 2015b.

20) For the researches of high plateau people in eastern Anatolia $c f$. Özfirat 2001a; Özfirat 2001b: 326-330; and Polat 2013.

21) Cilingiroğlu 1984: 129-140.

22) Burney 1958: 157-209. Cf. also Burney 1989: 45-51 as well as Burney and Lang 1971.

23) For the early Transcaucasian pottery tradition $c f$. Işı1klı 2011. 
on burial traditions in eastern Anatolia have slightly increased ${ }^{24}$, the ones in Ardahan region remain still much more limited where we also know kurgans of Kurtkale and Akçakale ${ }^{25}$.

Several Medieval chapels were found in Ardahan; Yanlızçam seems to be the major Medieval Georgian church so far. Also Medieval building in Kartalpınar is the sole civic building in Ardahan since the rescue excavations at Medieval Sazpegler in the region ${ }^{26}$.
In terms of Post-Medieval archaeology Molokan and Greek gravestones of $19^{\text {th }}$ and $20^{\text {th }}$ centuries are the major evidences of their archaeological existence in the region. A further and systematic study of these inscriptions will be published soon.

\section{A NOTE AND ACKNOWLEDGEMENT}

All the maps and drawings of this paper were produced by S. Patac1. We would like to thank to $\mathrm{Mr}$ A. Tibet (Istanbul) for the edition of this report.

S.P. and E.L. 


\section{ABBREVIATIONS AND BIBLIOGRAPHY}

Akyurt, İ. M., 2014: M.Ö. 2. Binde Anadolu'da Ölü Gömme Adetleri, Atatürk Kültür, Dil ve Tarih Yüksek Kurumu, Türk Tarih Kurumu Yayınları VI. Dizi, Sayı 49, Ankara.

Baumgartner, B., 2009: "Unknown and Less Known Georgian Monuments in Northeast Turkey", in Skinner, P., Tumanishvili, D. and. Shanshiashvli, A. (eds.), The Proceedings of the $1^{\text {st }}$ International Symposium of Georgian Culture: Georgian Art in the Context of European and Asian Cultures, June 21-29, 2008, Georgia. Georgian Arts \& Culture Center, Tbilisi: 183-187.

Bayram, F., 2005: Artvin'deki Gürcü Manastırlarının Mimarisi, Istanbul.

Bayram, F. and Yazar, T., 2008: "Artvin, Erzurum, Ardahan İli ve İlçelerinde Gürcü Mimarisi Yüzey Araştırmas1-2006", AST 25/1: 263-284.

- 2011: “Artvin, Erzurum, Ardahan İli ve İlçelerinde Ortaçağ Gürcü Mimarisi Yüzey Araştırması-2009”, AST 28/1: 1-18.

- 2013: "Artvin, Erzurum, Ardahan İli ve İlçelerinde Ortaçağ Gürcü Mimarisi Yüzey Araştırması-2011”, AST 30/2: 321-336.

Burney, C. A., 1958: "Eastern Anatolia in the Chalcolithic and Early Bronze Age", Anatolian Studies 7: $37-$ 53.

- 1989: "Hurrians and Proto-Indo-Europeans: The Ethnic Contex of the Early Trans-Caucasian Culture", in Emre, K., Mellink, M., Hrouda, B. and Özgüç, N. (eds.), Anatolia and the Ancient Near East, Studies in Honor of Tahsin Özgüç, Ankara: 45-51.

Burney, C. A. and Lang, D. M., 1971: Peoples of the Hills: Ancient Ararat and the Caucasus, London.

Chant'uria, A. (tr.): "Mat'iane Kartlisa / The Chronicle of Kartli", in Jones, S. and Met'reveli, R. (eds.), Kartlis Tskhovreba / A History of Georgia, Georgian National Academy of Sciences, Commission for the Study of Georgian Historical Sources, Tbilisi: 141-170.

Çilingiroğlu, A., 1984: "The Second Millenium Painted Pottery Tradition of the Van Lake Basin", Anatolian Studies 34: 129-140.

Edwards, R. W., 1986 : "The Fortifications of Artvin: A Second Preliminary Report on the Marchlands of Northeast Turkey", Dumbarton Oaks Papers 40: 165182.

- 1988: "The Vale of Kola: A Final Preliminary Report on the Marchlands of Northeast Turkey", Dumbarton Oaks Papers 42: 119-141.

Gündoğdu, H., 2000: Kaleler ve Kuleler Kenti Ardahan, T.C. Ardahan Valiliği Kültür Yayınları No: 4, Ankara.

- 2001: Tarihi Kalıntıları ile Çıldır, Ankara.

Iş1klı, M., 2011: Doğu Anadolu Erken Transkafkasya Kültürü (Çok Bileșenli Gelişkin Bir Kültürün Analizi, Istanbul. York.
Kadiroğlu, M., 1999: "Untersuchungen an mittelalterlichen georgischen Baudenkmälern in Nordost-Anatolien", Georgica 22: 8-19.

- 2000: "Çoruh Havzası Ortaçağ Gürcü Mimarisi Araştırmaları", Türk Arkeoloji ve Etnografya Dergisi 1: 81-86.

Kadiroğlu, M., Yazar, T., Bayram, F. and İşler, B., 2005: "Çoruh Havzası Ortaçağ Gürcü Mimarîsi 2003 Y11 Yüzey Araştırması”, AST 22/2: 93-106.

Kadiroğlu-Leube, M., 1998: “Ortaçağ Gürcü Mimarisi 1996 Yı1ı Yüzey Araştırması”, AST 15/1: 97-125.

Kadiroğlu Leube, M., Yazar, T. and Karaca, Z., 1997: “1995 Yı1ı Tao-Klardjetie Yüzey Araştırması”, AST 14/1: 397-421.

Kökten, İ. K., 1944: “Orta, Doğu ve Kuzey Anadolu'da Yapılan Tarih Öncesi Araştırmaları” Belleten 8: 659-680.

- 1953: "1952 Yılında Yaptığım Tarihöncesi Araştırması”, Ankara Üniversitesi, Dil ve Tarih-Coğrafya Fakültesi Dergisi 2: 177-209.

Köroğlu, K., 1997: “1995 Y1lı Artvin-Ardahan İlleri Yüzey Araştırması”, AST 14/1: 369-395.

- 1999: "1997 Y1lı Artvin-Ardahan İlleri Yüzey Araştırması", AST 16/1: 143-160.

- 2000: "Çıldır Kurganları / The Kurgans of Çıldır", Arkeoloji ve Sanat 96: 2-11.

Özfirat, A., 2001a: "Research on the Cultures of East Anatolia in the $2^{\text {nd }}$ Millenium B.C.", in Belli, O. (ed.), Istanbul University's Contributions to Archaeology in Turkey (1932-2000), Istanbul University Rectorate Publication No 4285, Istanbul: 326-330.

- 2001b: Doğu Anadolu Yayla Kültürleri (M.Ö. II. Binyll), Arkeoloji ve Sanat Yayınları, Eski Anadolu Uygarlıkları Dizisi 5, Istanbul.

- 2003: “Doğu Anadolu Yüksek Yaylası'ndan M.Ö. 2. Biny1l Kurganları", Belleten 66, 246: 343-356.

- 2009: "Bozkurt Kurgan Mezarlığı Kazıları", Belleten 73, 268: 635-644.

- 2010: "Bozkurt Kurgan Mezarlığ1. Yerleșik Kültür Geleneğinin Sonu: Kurganlar”, Aktüel Arkeoloji Dergisi 15: 42-43.

- 2012: "Earlier Settlements of Bozkurt Kurgan Cemetery: from Chalcolithic to Middle Bronze Age", in Ragimova, M. N. (ed.), Early Farming Cultures of Caucasus, International Scientific Conference, Baku 03-06 November 2011, National Academy of Sciences of Azerbaijan, Institute of Archaeology and Ethnography, Baku: 113-127.

- 2014: "Bozkurt Kurgan Mezarlığından Ayrışık Bir Kap", in Çinardalı-Karaaslan, N., Aykurt, A., KolankayaBostanc1, N. and Erbil, Y. H. (eds.), Anadolu Kültürlerine Bir Baklş: Armağan Erkanal'a Armağan / Some Observations on Anatolia Cultures: Compiled in Honor of Armă̆an Erkanal, Hacettepe Üniversitesi Yayınları, Ankara: 319-326.

Patac1, S., 2015a: “Ardahan İli 2013 Y1l Arkeolojik Yüzey Araştırması”, AST 32/1: 99-116. 
- 2015b: "Archaeological Surveys of Ardahan in Northeastern Anatolia in 2013", in Lafl, E. and Patac1, S. (eds.), Recent Studies on the Archaeology of Anatolia, Colloquia Anatolica et Aegaea, Acta congressus communis omnium gentium Smyrnae III, British Archaeological Reports, International Series, Oxford.

Patacı, S. and Küçük, L., 2015: "Medieval and PostMedieval Christian Societies and Architecture in Ardahan", in Lafl, E. and Patac1, S. (eds.), Recent Studies on the Archaeology of Anatolia, Colloquia Anatolica et Aegaea, Acta congressus communis omnium gentium Smyrnae III, British Archaeological Reports, International Series, Oxford.

Patacı, S. and Lafl1, E., 2014: "Kafkasya Arkeolojisinde Yeni Gelişmeler: Ardahan İli Yüzey Araştırması - 2013", Türk Eskiçă̆ Bilimleri Enstitüsü, Haberler 38: 32-34. - 2015a: "Ardahan İli 2014 Y1l Yüzey Araştırmaları", Türk Eskiçă̆ Bilimleri Enstitüsü, Haberler 39: 26-28.

- 2015b: “Ortaçağ ve Sonrasında Ardahan'daki Ermeni ve Diğer Hristiyan Toplulukların Arkeolojisi”, Arkeoloji ve Sanat.

Patac1, S. and Oral, Ö., 2015: "Medieval Georgian Archaeology in Ardahan according to the Results of the Latest Studies", in: $3^{\text {rd }}$ International Conference, TaoKlarjeti, National Centre of Manuscripts, 17-21 October 2014, Tbilisi.

Polat, F., 2013: Doğu Anadolu Yayla Kültürü ve Yayla Mimarisi, Istanbul.

Salia, K., 1983: The History of the Georgian Nation, Paris.

Soviet Armenian Encyclopedia (SAE), 1976: s.v. "Ardahan", Armenian Academy of Sciences, Yerevan, Vol. II: 7.
T’aqaishvili, Ekh., 1909: “Христианские памятники, (Экскурсия 1902 года)", Материаль по археол. Кавказа, собран. экспед. Имп. Моск. археол. о-ва. Вып. 12: 84117.

- 1924: Kharthuli hurothmodzgiwrebis albomi, Nahazebi šerrnlebulis hurothmodżंwartha da mhatwartha Ebralidzisa / Album d'architecture géorgienne, Universitetis gamocema, Tbilisi.

- 1938: Expédition archéologique en Kola-Olthissi et en Tchangli, Paris

$<$ http://dspace.nplg.gov.ge/bitstream/1234/10599/1/

TaKaishvili Eqvitime 1938.pdf> (15/07/ 2015).

Tekinalp, V.M. and Ekim, Y., 2006: Sazpegler, Kuzeydoğu Anadolu'da Bir Ortaçă̆ Yerleşimi/Sazpegler. A Medieval Settlement in North Eastern Anatolia, Gazi University Research Center for Archaeology, Baku-Tbilisi-Ceyhan Crude Oil Pipeline Project Publications of Archaeological Salvage Excavations 3, Ankara.

Tunç, Z., 2015: "Fortresses of Ardahan in Classical Antiquity", in Lafl, E. and Patac1, S. (eds.), Recent Studies on the Archaeology of Anatolia, Colloquia Anatolica et Aegaea, Acta congressus communis omnium gentium Smyrnae III, British Archaeological Reports, International Series, Oxford.

Yükmen, B., 2003: Doğu ve Güneydoğu Anadolu Dolmenleri Işı̆̆ında Anadolu Megalitleri, Arkeoloji ve Sanat Yayınları, Eski Anadolu Uygarlıkları Dizisi 7, Istanbul. 


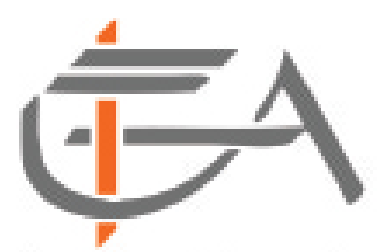

Institut Français d'Etudes Anatoliennes

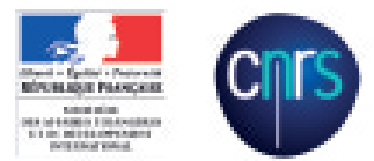

Eglise paléochrétienne de Bindéos (Pisidie), détail de la mosaïque ornant le sal de la nef centrale, $4^{e} \mathrm{~s}$. ap. J.-C. 